\title{
Performance and strategy: simultaneous equations analysis of long-lived firms
}

Bernadette Power and Gavin C. Reid

This is an Accepted Manuscript of an article published by Taylor \& Francis in International Journal of the Economics of Business on 18th August 2015, available online:

http://wwww.tandfonline.com/10.1080/13571516.2015.1051751 


\title{
Performance and Strategy: \\ Simultaneous Equations Analysis of Long-lived Firms
}

\section{By}

\author{
Dr. Bernadette Power ${ }^{+}$and Prof. Gavin C Reid ${ }^{++}$
}

\begin{abstract}
A simultaneous equations model of performance, strategy and size is tested using fieldwork evidence on long-lived firms in Scotland. Estimation is by I3SLS, with correction for sample selection bias. The contributions of this paper are that it: (a) grounds estimation on fieldwork evidence; (b) calibrates performance and competitive strategy; (c) tests and models endogeneity; and (d) computes robust trade-off elasticities between firm size and performance. It shows how this trade-off provides the entrepreneur with two strong incentives: (i) to seek greater efficiency typically by an increase in the human capital of the 'core' workforce; (ii) to achieve higher levels of performance by adopting more diverse competitive strategies.
\end{abstract}

\section{Keywords: $\quad$ Performance, Size, Competitive Strategy, Simultaneity, Mature Firms}

\section{JEL: $\quad$ C42, D21, G33, L2, M13, M21}

${ }^{++}$Author for Correspondence: Honorary Professor of Economics, School of Economics and Finance, University of St. Andrews, St. Salvator's College, St. Andrews, Fife, Scotland, KY16 9AL, UK.*

e-mail: $\quad$ gcr@st-andrews.ac.uk

Phone/Fax: (+44) (0) 1334462431 (personal); (+44) (0) 1334462438 (CRIEFF)

www: http://www.st-andrews.ac.uk/economics/staff/gcr.html

${ }^{+}$College Lecturer, School of Economics, University College Cork, Cork, Ireland

e-mail: b.power@ucc.ie

Phone: $(+353)(0) 214902986$

Fax: $\quad(+353)(0) 214273920$

www: http://publish.ucc.ie/researchprofiles/B008/bpower

This work was supported by the Enterprise Ireland under Grant [IC/2001/060].

* Now Dean, Dundee Business School, Abertay University, Bell Street, Dundee, DD1 1HG 


\title{
Performance and Strategy: \\ Simultaneous Equations Analysis of Long-lived Firms
}

\begin{abstract}
A simultaneous equations model of performance, strategy and size is tested using fieldwork evidence on long-lived firms in Scotland. Estimation is by I3SLS, with correction for sample selection bias. The contributions of this paper are that it: (a) grounds estimation on fieldwork evidence; (b) calibrates performance and competitive strategy; (c) tests and models endogeneity; and (d) computes robust trade-off elasticities between firm size and performance. It shows how this trade-off provides the entrepreneur with two strong incentives: (i) to seek greater efficiency typically by an increase in the human capital of the 'core' workforce; (ii) to achieve higher levels of performance by adopting more diverse competitive strategies.
\end{abstract}

\section{Keywords: $\quad$ Performance, Size, Competitive Strategy, Simultaneity, Mature Firms}

JEL: $\quad$ C42, D21, G33, L2, M13, M21

\section{Introduction}

This paper presents a micro-micro-econometric analysis ( $c f$. Leibenstein 1992) of the relationship between firm size, the diversity of competitive strategy and performance for a sample of Scottish, long-lived and typically small firms. We contribute to the growing empirical literature on firm growth and performance which seeks to explain why firms tend to remain small (De and Nagari 2014; Hsieh and Klenow 2012; and Henrekson and Johansson 1999, 2010). Indeed, there is emerging evidence of a shrinking in firm size, as measured by employment, across western economies, such as the United States, United Kingdom, France, Germany, and Italy, see Rosa and Hanoteau (2012) and Dosi et al. (2008). Alas, recent work overemphasises fast growing firms (see Segarra and Teruel 2014; Arrigheti and Lasagni 2013; Lopez-Garcia and Puente 2012; Barringer, Jones and Neubaum 2005; Delmar, Davidsson and Gartner 2003; and Almus 2002), even though they are atypical. The typical 
firm achieves only moderate growth and often remains small (i.e. less than 50 employees: 2003/361/EC-definition), or even contracts. Though fast growing firms provide new employment in the small firm sector ${ }^{1}$, long-lived small firms provide continued employment in communities, and create positive externalities over time.

Many barriers to growth of the small entrepreneurial firm (e.g. financial, motivational, organizational) have been identified (Coad and Tamvada 2012; Davidsson, Achtenhagen and Naldi 2010; Wiklund, Shin and Taejong 2003; Henrekeson and Johnsson 1999; and Heneman, Tanksy and Camp 2000) but further study is required of how they inhibit growth, see Barber, Metcalfe and Porteous (1989) and Petrakis (1997). Size has different significance for large compared to small firms. For example, Lee (2009) has found that for large publically traded US companies there is a positive relationship between size and performance. The importance of both initial start-up size (Mata and Portugal 1994; and Strotmann 2007) and current size (Mata, Portugal and Guimarães 1995) have been emphasised in studies of small firm survival and post-entry growth, yet the tendency for firms to remain small has been neglected.

Contrary to Lee's (2009) findings for large firms, in small firms a control motive by the entrepreneur can limit output growth, denying the firm efficiency gains from growth. Given fixity of the entrepreneurial input, limits (e.g. of cognition) to the span of control encourage diminishing returns. This leads to a trade-off between size and performance (Lucas 1978; van Praag and Cramer 2001). Other barriers to growth can interact negatively with the long run performance of the firm. Dhawan (2001) argues a small firm can avoid this is by being creative about its strategies e.g. by building a niche in the market. Thus, we hypothesise that the diversity of the firm's competitive strategy (e.g. adopting computer systems, entering overseas markets) can raise its performance, and that increases in its performance can raise the diversity of its competitive strategy. This engenders the size-performance trade-off which limits the size of the firm, yet has a positive impact on performance. This effect acts jointly 
with the trade-off relationship between size and performance to foster a sustained (but smallscale) existence of the firm.

We model the above, using a simultaneous three equations model ( $c f$. Carmignani 2011) estimated by iterative three stage least squares, I3SLS, (see Greene, 2011) on a cross-section of data with firms indexed by $i$. It adopts a modern variant of the Structure Conduct Performance (SCP) paradigm (Resende 2007; Sahoo and Mishra 2012; Setiawan, Emvalomatis and Lansink 2013) Briefly, the model's three endogenous variables are $P$ (Performance $\left.{ }_{\mathrm{i}}\right), S\left(\right.$ Size $\left._{\mathrm{i}}\right)$, and $C\left(\right.$ Strategy $\left._{\mathrm{i}}\right)$ and the exogenous variables are in three sets, $\boldsymbol{X}_{\boldsymbol{l}}$, $\boldsymbol{X}_{2}$ and $\boldsymbol{X}_{3}$. In compressed form the model is represented by equations:

$$
P=f\left(S, C, X_{1}\right) \quad(1) ; \quad S=g\left(P, X_{2}\right) \quad(2) ; \quad \text { and } C=h\left(P, X_{3}\right)
$$

We find I3SLS corrected for sample selectivity converges rapidly (usually within two iterations). Our sample constitutes unique Scottish primary evidence, permitting detailed micro-micro analysis (Leibenstein 1979) of the complex operations of (largely) small firms. This evidence was created by fieldwork activity, over three decades, and involved 'hybridising' three parent samples to create a novel database.

Briefly, our estimation reveals a trade-off between the firm's size (S) and performance (P). Further, the negative consequences for firm growth can be averted e.g. by efficiency gains and by the use of more diverse competitive strategies. Actually, this trade-off provides incentives for owner-managers to strive for (a) greater efficiency typically by an increase in the human capital of the 'core' workforce, (see Farinas and Ruano 2003; Illucea and Lafuente 2003); and (b) higher levels of performance (P), by more diverse competitive strategies (C), in niche or localised markets, Dhawan (2001).

The development of the paper is as follows. Section 2 briefly reviews the extant literature, and Section 3 explains how our Scottish data were collected by fieldwork. Section 4 reports on endogeneity tests and how our simultaneous equations system was specified. Section 5 reports on how we estimated the behavioural relations between firm size, 
competitive strategy and performance, using iterative three stage least squares. Finally, Section 6 summarises our principal results.

\section{Literature}

Our work builds on the literature of firm growth and performance and modern approaches to the SCP paradigm to explain the tendency for the firm to remain small. To illustrate, Feldman and Klofsten (2000) argue barriers to growth can be due to poor 'governance systems' within firms, leading to strategic deficiencies e.g. limited ability to plan, to manage, and to allocate resources effectively. Further limits to growth may involve poor communications, bureaucracy, and loss of entrepreneurial spirit. This goes beyond the earliest limits to growth arguments, e.g. Penrose (1959) and Richardson (1964), and formalisations like Slater (1980), and empirical tests like Reid (1998). Further, the modern focus is on issues like: firm size, organization and strategy, Stam (2010), Parker, Storey and Witteloostuijn (2010); geographical location and size, Barbosa and Eiriz (2011); sample selectivity and size, Pfaffermayr (2007); and learning, knowledge, competencies and size, Bonaccorsi and Giannangeli (2010), Lotti, Santarelli and Vivarelli (2009) and Colombo, Delmastro and Grilli (2004).

Parker, Storey and Witteloostuijn (2010) consider five diverse areas of strategy (e.g., innovation, governance, marketing) to explain fast growth in middle market firms in the UK. They find dynamic strategies more successful than static ones; and strong marketing and a solid main product foster rapid growth. We too examine the influence of strategy, especially the diversity of strategy. Theoretical work by the likes of Aloysius, Deck and Farmer (2012), also explores diverse pricing strategies, similarly expanding our concept of strategy away from the unitary approach (e.g. a cost leadership strategy). Our approach to strategy focuses on drivers of sales, e.g. marketing, new products, and after-sales. We refer to this enlargement of the strategy domain as the diversity of the firm's competitive strategy. 
Other studies sympathetic to extending the SCP approach include Barbosa and Eiriz (2011) on industrial diversity in Portuguese manufacturing, Pfaffermayr (2007) on Austrian manufacturing and service firms, and Colombo, Delmastro and Grilli (2004) on competencies. Bonaccorsi and Giannangeli (2010) also suggest that competencies are important and model a threshold effect on size. Of these diverse approaches, the most extensive findings are reported on the performance, size and growth nexus. To better understand these findings, important considerations include; a) the technological level, see Stam and Wennberg (2009); b) the lifecycle phase, Hennrekson and Johannsson (2010); c) the maturity, Stam (2010), and d) the knowledge intensity, Huggins (2011). These works emphasise how competition encourages small firms active in global markets to innovate, and to make superior use of their core competences and knowledge base. That work, like ours, uses interview data to create micro-micro data for analysis.

A classical way of addressing the performance, size and growth nexus is in terms of Gibrat's Law, see Sutton (1997). This has been widely tested, for example by Singh and Whittington (1975), who unusually seem to find that big firms grow faster than small firms. However, the empirical orthodoxy, under a wide variety of tests, over time and across countries, is that small firms grow faster than large firms, Santarelli, Klomp and Thurik (2007). Extensions of this work are in Mukhopadhyay and Kalkhali (2010), who find no evidence for the notion that higher profitability leads to higher growth for small firms. This confirms the growth-profitability trade-off for small firms noted first for a sample of Scottish start-ups in Reid (1995). Rogers, Helmers and Koch (2010) examine deciles of the firm size distribution to test Gibrat's Law, and also find estimates refute Gibrat's Law, but the findings are sensitive to the deciles. The apparently varied interpretations of the validity or otherwise of Gibrat's Law have been reconciled by the work of Lotti, Santarelli and Vivarelli (2009) who argue that whilst Gibrat's Law is refuted ex ante, it is sustained ex post, in that once the 
market has purged less efficient firms by selecting them out, the remaining firms display Gibrat-like growth patterns.

Broadening the scope of studies that depend purely on mechanisms, as represented by random processes, as in Luttmer (2011) for example, writers like Leitner and Güldenberg (2010) emphasise small business strategy, of the Porter (1980) variety, in which small business planning plays a key role. Extending Porter's use of 'single element' strategies, like cost leadership, they find instead that what they call 'combination' strategies, involving a hybrid of several strategic elements, tend to produce better small business performance and growth than do single element strategies. Further developments of this line of reasoning lead to the diversity of competitive strategy approach, which we adopt. Such research includes contributions from Lee (2009) and Covin and Slevin (1989). For example, in the latter, strategies are not unitary, but embrace organizational, financial and pricing structure, as well as forecasting, product development etc. In this paper, we specifically examine the relation between firm size, competitive strategy and firm performance in a three equation simultaneous model to capture jointly determined elements of strategy.

While the foundations of the SCP (Structure-Conduct-Performance) approach, as developed in the discipline of industrial organization, has some bearing on our approach, it does not imply that we follow the founding version of this, by Bain (1951) and Mann (1966). They would see a direct causality from structure (like market concentration), to conduct (like profit maximization), to performance (like mark-up on marginal cost). Reid (1987) reviews the genesis of these ideas, but argues that as the years have passed since the foundation of $\mathrm{SCP}$, the interpretation of the framework has became increasingly sophisticated. Thus, writers like Phillips (1976) and Geroski (1982) recognised possibilities of endogeneity (e.g. of structure being influenced by performance), and two-way causality (e.g. between conduct and performance). 
Modelling these effects, and testing for their existence, became possible with development of new econometric methods and associated software, especially those for estimating simultaneous equations systems. Typical of the latter approach in recent years are the studies: by Resende (2007) of Brazilian manufacturing; by Delorme et al. (2002) of US manufacturing; by Sahoo and Mishra (2012) of Indian banking services; and by Setiawan, Emvalomatis and Lansink (2013) of Indonesian manufacturing, all of which use different types of simultaneous equation methods, though not always with the detailed attention to testing for endogeneity which we have given. With only a few recent exceptions [e.g. by Goldberg, Gruenfeld and Benito (2008) on Norwegian firm-level census data; and by Liu, Zhao and Liao (2013) on construction in PR China] which ignore simultaneity and mutual causality, the argument is now recognised amongst economists of industry and business that SCP can (and should) embrace endogeneity. This is the approach we adopt in our paper.

A further strand of analysis has re-emerged, which is the use of a qualitative (rather than econometric) approach to SCP reasoning, which harks back to the founder's treatment, yet recognises modern adaptations of this approach to embrace endogeneity and mutual causality. To illustrate, Anthony, Caudill and Mixon Jnr. (2012) take a historical perspective on women's basketball, and use the SCP framework to trace and explain its evolution in the US; and Sivramkrishna (2014) too, uses SCP in a narrative rather than econometric fashion to show how the East India company grew from being an economic power to become a political power. Finally, Spulber (2013), writing as a specialist in regulation, law and economics, in the context of innovative economics, has favoured embracing endogeneity, and dynamics, in a narrative rather than econometric form. In our current study of long lived firms, we are influenced by both approaches, the narrative and the econometric, but their common feature is that they do allow for mutual causality and endogeneity. 
The literature on performance is extensive, very often focussing on different dimensions of performance. For example, Francis et al. (2011) focus on product differentiation, Younsuk, Shin and Kim (2012) on industrial networking, Van der Stede, Chow and Lin (2006) on quality based strategy, Steffens, Davidsson and Fitzsimmons (2009) on strategic entrepreneurship, and Bonaccorsi and Giannangeli (2010) on growth and profitability. One could even take a wider view of performance, like Hmieleski and Baron (2009) who link the entrepreneur's optimism to performance. More generally, Wall et al. (2004) argue, as we do, that a subjective measure of company performance is both more encompassing, and reliable, as a consistent measure of performance. They show that subjective measures have strong qualities, identified as convergent, discriminant and construct validity.

Recent applications of the simultaneous equations approach include Chen (2006), Resende (2007) and Shyu (2011). Chen (2006) used a switching simultaneous-equations model to examine the relation between ownership and firm performance. Resende (2007) used three stage least squares to investigate the structure, conduct and performance paradigm in the Brazilian Manufacturing Industry. Shyu (2011) uses two stage least squares to examine the influence of family ownership on firm performance. Other examples in the literature include Jans and Rosenbaum (1996), Beccarello (1997) and McDonald and Bloch (1999). The latter, McDonald and Bloch (1999), use instrumental variables to estimate the spillover effects of an industrial growth/performance trade-off model. Inspired by these papers, we use I3SLS to estimate a three-equation size/performance trade-off model with a correction for sample selection bias.

\section{Data}

\subsection{Sample Composition}


Briefly, the data set that we used was based on interview evidence obtained from ownermanagers of long-lived firms in Scotland. They were obtained from a sampling frame of three "parent" samples of Scottish small medium sized business enterprises (SMEs) ${ }^{2}$, upon which we created further fieldwork evidence. These parent samples will be described as the Leverhulme (1985-1988), Telephone Survey (1991) and Leverhulme (1994-1979) 'parent samples', for expositional purposes (see Table 1). The owner managers of businesses in these three parent samples were interviewed by Reid in the 1980s and 1990s. The fieldwork behind the Leverhulme (1985-1988) sample involved gathering data by face-to-face interviews with the owner managers of 86 new business starts in Scotland in the late 1980 's. ${ }^{3}$ Of these 86 firms, 25 (29\%) survived and 20 of these agreed to be re-interviewed for this study. Data on the second sample frame of 160 mature firms (Telephone Survey 1991), were attained from the list of members of the Federation of Small Business (FSB) in Scotland. ${ }^{4}$ These data were collected by structured interviews over the telephone in 1991. At that time, 107 firms agreed to be interviewed. Fifty of the original 107 firms from this parent sample were still in business in 2001 (a survival rate of 47\%). Thirty of these firms agreed to be reinterviewed. From the Leverhulme (1994-1997) sample, our third parent sample, made up of 150 relatively young firms, we found another 20 long-lived firms (founded prior to 1991), aged 10 years or more..$^{5}$ In the latter case, the original sample was intentionally of new business starts. These firms' owner-managers were first interviewed, face-to-face, annually over the interval 1994-1997. Fifteen out of twenty firms aged 10 or more were still trading (a survival rate of $75 \%$ ). Thirteen of these agreed to be re-interviewed.

\section{[INSERT TABLE 1 HERE]}

The three parent samples are known to provide a good representation of the relevant populations of micro, small and medium sized firms in Scotland at the time of selection. In total, we gathered a cross-section of new additional data on 63 long-lived SMEs, by face-toface interviews, between October 2001 and February 2002, using Enterprise Ireland funding. 
The administered questionnaire we created for this purpose examined the following characteristics of the long-lived firm: changes in its scale and scope; pivotal changes in its running since start-up; factors which fostered its survival; and its level of innovation and technical change.

The firms examined were mature (25 1/2 years on average; median age of 22 ), hence our regarding them as 'long lived'. Almost all sectors, by SIC code, were represented in the sample, running through from agriculture (01) to domestic services (99). The main sectors, by SIC codes, were: 32, mechanical engineering (4.8\%); 43, textile industry $(4.8 \%)$; 61, wholesale distribution (4.8\%); 64, retail distribution (23\%); 66, hotels and catering (4.8\%), 67, repair of consumer goods and vehicles (6.3\%); and 83 business services $(9.5 \%)$. Thus, the modal firm was a retailer. The sample proportions between extractive/manufacturers (SIC 01-60) and services (SIC 61-99) were $40 \%$ and $60 \%$ respectively. These proportions were similar across the extracted and interviewed 'parent' samples (see Table 2).

\section{[INSERT TABLE 2 NEAR HERE]}

Of the 213 firms in our three parent samples, 82 (38\%) were in manufacturing (SIC 01-60), and $131(62 \%)$ were in services (SIC 61-99). Figures from the Department of Trade and Industry, for the UK as a whole, over a comparable time period, indicate that $27 \%$ were in extractive/manufacturing and $73 \%$ were in services. The following regions were represented: Aberdeen, Argyll, Aryshire, Banff, Caithneas, Cumnock, Dundee, Fife, Glasgow, Inverness, Isle of Skye, Lanarkshire, Lothian and Edinburgh, Midlothian, Moray, Orkney, Perth, Renfrewshire, Ross and Stirling. These represent well the locational diversity of long-lived firms in Scotland.

Table 3 lists the key variables used in our econometric estimation, and displays their summary statistics. We detail the construction of the key variables below.

\subsection{Performance}


Our quantitative indicator of performance was multidimensional, involving 28 items, each of which was calibrated on a 100-point scale, see Figure 1 for an extract of the survey question which shows this calibration and/or the more detailed online appendix to view the exact survey question administered which lists all 28 items included in this multidimensional measure. We argue like Kiviluoto (2013) that more holistic measures than sales growth are required to understand the complexity of firm success. There are many dimensions to firm performance. Our indicator examined these dimensions of performance under main headings like strategic (9 items), financial (4 items), organisational (4 items) and environmental (11 items). We hold that our approach has advantages over financial measures alone. Those are limited by accounting conventions (e.g. the reporting protocol). Further, lifecycle effects may make them difficult to interpret in sensible economic terms. For example, up to three years of losses are commonly 'factored in' to early business planning. Further, accounting profit is not readily related to economic profit. Thus, a univariate measure like the rate of return, or profitability, may fail to grapple with quite simple aspects of reality. For example, profit itself may be ill-defined in many owner managed firms, as the distinction between profit and income are often blurred. A single self-appraised question on performance could have been used, but our multidimensional approach has two main advantages. First, it creates detailed measurement across the spectrum of performance-relevant variables, rather than a single variable. Second, by reducing variable specific effects, it produces a more comprehensive (and stable) measure of performance, allowing common influences to come through (DeVellis, 1991).

\section{[INSERT TABLE 3 NEAR HERE]}

The key performance question put to owner-managers was as follows: "We'd like to know what has kept you in business down the years. Some things are good for business and some things are bad. What effect have the following had?". The owner-managers were asked to rate each of the 28 items on a scale of 0 to 100 where 100 is good, and 0 is bad and 
50 is neutral. They did so by placing a cross on a line of length 100 units. Thus, we finely calibrated the influence this item had, based on experience of running the business. If an item was not applicable, respondents were asked to say so. The format we used is displayed, in an abbreviated way, in Figure 1 (e.g. operational efficiency, cash-flow, debt etc.) ${ }^{6}$. Recent examples of the successful use of data generated in this way include the work of Dickey, Watson and Alexandros (2011), and Ochsen (2011). The former investigated the financial status of individuals (using a five point scale), and their perceived health over a twelve month period (also using a five point scale). The latter estimated life satisfaction using a four point scale.

\section{[INSERT FIGURE 1 NEAR HERE]}

We found that owner-managers could readily able to draw on their experience in selfappraising items about performance. In doing so, they drew on a large body of qualitative and quantitative evidence, in making their judgements. To illustrate, over time they learnt to combine factors of production effectively; and they had learned how to respond to threats in a way that improved performance and survival. Given that owner-managers comfortably juggle these various performance measures in their own minds, we consider it logical to seek explicit measures of how this juggling act is sustained. Thus our measuring exercise provides us with a new form of empirical evidence, based on judgements, which nevertheless is useful in econometric estimation. From these self-assessments an overall score for performance (Performance $_{i}$ ) was calculated for each firm, based on the summation of ratings for factors, normalised to take account of those items that were not applicable. For instance the sum of the self-assessed ratings [0 to 100] of 20 individual scale items for a steel fabricator totalled 1,207. This overall score was then divided by 20 rather than the total of 28 scale items as 8 scale items were rated 'not applicable' to the long run performance of the steel fabricator. This measure is not age related, as each dimension may assume a greater or lesser importance at any point in the lifecycle. 
We did examine the possibility of applying multivariate statistical methods using principal axis factoring as an alternative to our composite indicator of performance, but our sample size constrained us from including all 28 items rated. Thus the composite indicator was thought to be more comprehensive. Our Performance index was found to have sound properties $^{7}$ following tests for internal consistency and for fit using multidimensional measurement models.

We demonstrate the validity of the composite performance indicator by examining correlations between this measure of Performance and more traditional accounting measures. Given the fixity of key factors, like the entrepreneurial input, one expects diminishing returns to scale. We indeed find that asset growth and our performance indicator are negatively correlated (Pearson's $\mathrm{R}=-0.298$, Prob. value<0.05) mimicking the relationship between accounting profit and asset growth (Pearson's $\mathrm{R}=-0.747$, Prob. Value $<0.0001$ ). Our Performance indicator was also negatively correlated with the level of indebtedness of the firm (Pearson's $\mathrm{R}=-0.208$, Prob. Value $<0.05$ ) in 2001 which we would also expect of traditional quantitative measures of performance. The semi-log-linear regression of the natural logarithm of profitability against our untransformed performance measure found that: $\ln ($ Profitability $)=1.0689+0.0292$ (Performance) with diagnostics: $\mathrm{F}(1,47)=4.17, \mathrm{R}^{2}=$ 0.0316, Prob-value $=0.0467$ and $t=2.06$, Prob-value $<0.05$. The elasticity of Profitability with respect to Performance was $1.97 \%$. This was obtained by using the following expression $b \cdot \bar{x}$ where $b$ is the estimated coefficient on our performance measure and $\bar{x}$ is mean performance. We thus find that a $1 \%$ increase in our Performance measure leads to a $1.97 \%$ increase in the Profitability.

Arguably, our subjective measure of Performance acts as a reasonably good proxy for other quantitative measures of firm performance. It also goes beyond narrow measures of performance to broader ones, along the lines of emerging literature by the likes of Kiviluoto (2013). It appears that entrepreneurs 'act' on their own appraisals. Contemporary methods 
for valuing the performance of a firm support our general approach. For example, economic value added (EVA) was used as a measure of firm performance by Pham, Suchard and Zein (2011) in examining endogeneities in the relation between governance and performance to assess the extent to which individual monitoring systems enhance firm performance and shareholder value. Chen, Yang and Lin (2012) also used EVA and market value added (MVA) as measures of firm success when investigating influence of technological diversification on firm performance.

\subsection{Strategy}

Our indicator of the diversity of competitive Strategy $(C)$ is calibrated by a count of the number of forms of competition used by the firm. To determine it, owner managers were asked: What form of competition is used in your principal market? Options included price, quality, volume, after sales service, new product development, advertising, and marketing, see our online appendix to view the survey question administered. In summing forms of competition, a count of ' 1 ' indicates the firm competes on just one dimension of competitive strategy (e.g. price alone) whereas a count of ' 8 ' indicates that it competes across many dimensions (e.g. price, quality, delivery). To illustrate, a steel fabricator competed only on price and received a diversity of competitive strategy score of just ' 1 '. By contrast, a retailer of antiques competed on all 8 forms of competition except marketing so received a $C$ score of ' 8 '. On average, our firms competed on 4.5 dimensions. Essentially, higher values of this Strategy variable $C$ represent a greater willingness to compete.

Typically the long-lived firms in our sample felt that rivalry within their market was strong and that the competitive environment had become more hostile since start-up. Nearly half (46\%) described competition as intense in all aspects such as price, quality etc.; over a third (39.7\%) thought competition was strong but weak in some aspects such as strong quality competition but weak price competition; an eighth (12.7\%) felt that competition was generally weak but strong in some aspects; and two percent $(1.6 \%)$ of firms felt that 
competition was generally weak in all aspects. An increase in the intensity of competition is not necessarily a negative phenomenon for firms subject to this pressure. Porter (1985) argues that intense competition promotes efficiency, that is, competitors who, by engaging in sharp and challenging rivalry, actually promote the innovativeness of incumbent firms, and hence improve their prospects of staying in business. Our examination of the diversity of competitive Strategy $(C)$ across various levels of intensity of competition, found no significant difference in the mean number of forms of competition adopted for various levels of intensity of competition $\left[\mathrm{F}_{(3,59)}\right.$ statistic $=0.127$, $\mathrm{p}$-value $\left.=0.944\right]$ or for various market positions $\left[\mathrm{F}_{(4,58)}\right.$ statistic $=0.501$, p-value $\left.=0.735\right]$ where market positions were defined as 'low', 'middle' and 'top' end of the market. A diverse competitive Strategy space is evident across all market positions: diverse strategies are therefore ubiquitous. An indication of how these diverse strategies have impact is given by our findings on product differentiation (ProdDiff). A significant difference was found in the mean number of forms of competition adopted across levels of differentiation $\left[\mathrm{F}_{(3,57)}\right.$ statistic $=3.42$, p-value $\left.=0.023\right]$. Long-lived firms, which have identical products to their rivals, compete on 3.6 dimensions; with similar products they compete on 4.26; and with different products to rivals they compete on 5.5. Here, it is the extent of product differentiation (compared to products of principal rivals) which is influencing the diversity of competitive strategy. Finally, we found the level of the diversity of competitive strategy was related to our long run Performance indicator [Pearson's $\mathrm{R}=0.274$, $\mathrm{p}$-value $=0.03<0.05]$ suggesting that more diverse competitive strategies (e.g. more niche-based strategies) are likely to increase the long run performance of the firm. We shall see in Subsection 5.4 the effect of a change in the diversity of a firm's competitive strategy on the size/performance trade-off.

\subsection{Size}

Firm Size $(S)$ is approximated by the number of full-time equivalent employees (FTEs). In computing this FTE measure of firm size, part-time staff or more flexible sources 
of labour are accounted for but receive half the weight of fulltime employees. As measured in 2001, these mature firms were, on average, just above the micro-firm upper range of 10 employees. They generated $£ 835,000$ in turnover and had assets valued at $£ 330,000$. The predominant firm type was still the micro-firm which was typical of the composition of the stock of businesses in Scotland at the time. The average Size was somewhat raised by the existence of a few large firms in the sample.

\section{Model}

This Section explains the rationale of our model. The central hypothesis is the mutual causality (i.e. endogeneity) between competitive Strategy, Size, and Performance, with the latter two being in a trade-off relation. The principal relations between Size $(S)$, competitive Strategy $(C)$ and Performance $(P)$ are now examined.

In most general terms, our three-equation model, inspired by the literature of Section 2 above, may be simply specified as follows. First, a performance equation, $P=f\left(S, C, \boldsymbol{X}_{1}\right)$, where $P$, an endogenous measure of Performance, is determined by both an endogenous measure of Size, $S$, and an endogenous measure of competitive Strategy $C$, expressed by an index of the diversity of competitive strategy, as well as by a first set of exogenous variables $\boldsymbol{X}_{1}$. Second, a size equation $S=g\left(P, X_{2}\right)$, where $\boldsymbol{X}_{2}$ is a second set of exogenous variables. Third, competitive strategy equation $C=h\left(P, X_{3}\right)$, where the diversity of competitive Strategy is determined by performance, and $\boldsymbol{X}_{3}$ is a third set of exogenous variables. We hypothesise that $\partial \mathrm{P} / \partial \mathrm{S}<0, \partial \mathrm{P} / \partial \mathrm{C}>0$ in $f(),. \partial \mathrm{S} / \partial \mathrm{P}<0$ in $g($.$) , and \partial \mathrm{C} / \partial \mathrm{P}<0$ in $h($.$) . Thus$ there is an inverse relation between size and performance with causality running both ways, in equations $f($.$) and g($.$) , and an inverse relation between competitive strategy and$ performance in equation $h($.$) . It is an equilibrium model in which equilibrium values S^{*}, C^{*}$ and $P^{*}$ are determined by joint solution of equations $f(),. g($.$) , and h($.$) .$

In equation (1), $P=f\left(S, C, X_{I}\right)$, Size is expected to affect Performance negatively (i.e. a trade-off exists between firm size and performance), whereas competitive Strategy $C$ is 
expected to influence performance positively, ceteris paribus. The latter arises from Porter (1985) on 'good competitors' who engage in sharp and challenging rivalry that promotes the efficiency and innovativeness of incumbent firms, and hence improve their prospects of staying in business. The overall effect on performance depends on the relative sizes of these effects. $X_{1}$ here represents attributes of the financial structure of the firm, and aspects of its market and age. Equation (2) $S=g\left(P, X_{2}\right)$ represents Size as a function of Performance, and other exogenous variables. A negative relationship is expected here between size and performance. $\boldsymbol{X}_{2}$ incorporates lagged performance variables and other variables, like the resources of the firm (generating hidden costs to increasing firm size). Equation (3) $C=h(P$, $\boldsymbol{X}_{3}$ ) represents the diversity of competitive Strategy as a function of Performance and other exogenous variables. The sign of the Performance effect upon competitive Strategy is to be discussed. $\quad \boldsymbol{X}_{3}$ incorporates market structural variables to approximate the extent of external competitive pressure in the firm's principal market.

Changes in the judgement of firm performance should lead the firm to modify factors like its size, and its management processes, to enhance performance. The consequences of this will in turn modify performance judgements. Thus, this variable is expected to be endogenous within our simultaneous equations framework. The model has thirteen variables. Three of these are endogenous, performance, size and strategy. There are 8 exogenous variables in the model, which function to improve specification, goodness of fit, and to 'identify' the system, in a statistical sense. The variables used in each equation are explained in the Table 3.

Essentially this three-equation model allows us to examine whether a trade-off exists between the Size of the firm and its Performance; and, if it does, the influence that the diversity of the firm's competitive Strategy has on this trade-off. In general, it is expected that the greater the diversity of the firm's competitive Strategy, the higher the firm's Performance. Prescriptively, to survive, the mature firm must become leaner and more 
efficient, and must provide a more customised service. The consequence of this is a tendency for the firm to remain small, using differentiated strategies to target localised or niche markets.

The general model of equations (1), (2) and (3) is expressed in linear form (with $i$ denoting the $i$ th firm in the cross-section, and additive error terms $u_{i}$ ) in equations (4) to (6):

$$
\begin{array}{lllll}
\text { Performance }_{\mathrm{i}}= & \beta_{0} & +\beta_{1} \text { Size }_{\mathrm{i}} & +\beta_{2} \text { Strategy }_{\mathrm{i}} & +\beta_{3} \text { TechnicalChange }_{\mathrm{i}} \\
& +\beta_{4} \text { Liabilities }_{\mathrm{i}} & +\beta_{5} \text { Mainmarket }_{\mathrm{i}} \quad+\beta_{6} \text { Age }_{\mathrm{i}} \quad+\beta_{7} \text { Age }_{\mathrm{i}}{ }^{2} & +\mathrm{u}_{1}
\end{array}
$$

Size $_{\mathrm{i}}=\alpha_{0}+\alpha_{l}$ Performance $_{\mathrm{i}} \quad+\alpha_{3}$ TechnicalChange $_{\mathrm{i}}$

$$
+\alpha_{4} \text { BaseSalesRatio }_{\mathrm{i}} \quad+\alpha_{5} \text { OrgCap }_{\mathrm{i}}+\mathrm{u}_{2}
$$

Strateg $_{\mathrm{i}}=\gamma_{0}+\gamma_{1}$ Performance $_{\mathrm{i}}+\gamma_{2}$ Rival $_{\mathrm{i}}+\gamma_{3}$ ProdDiff $_{\mathrm{i}}+\mathrm{u}_{3}$

Initially, a priori considerations were used to classify variables as either exogenous or endogenous. Indeed the selection of $P, S$ and $C$ as endogenous arises as much from the extant literature, as from statistical considerations. However, once a priori knowledge has been incorporated in the model, its legitimacy needs to be explored econometrically. Therefore, formal tests for endogeneity within the system are examined below.

This following sections (4.1 and 4.2) reports on two matters: (a) Durbin-Wu-Hausman type tests of exogeneity; and (b) appropriate ways in which our system of equations can be estimated.

\subsection{Tests of Endogeneity}

Durbin-Wu-Hausman tests were applied to investigate whether the set of estimates of the structural equations obtained by least squares are consistent or not (Cameron and Trivedi, 2005, 276). If the null hypothesis that ordinary least squares (OLS) estimates are consistent is 
rejected, endogeneity (i.e. not every regressor being asymptotically independent of the disturbances) is present, and the instrumental variable estimator is preferred to the OLS estimator (Davidson and MacKinnon, 1993, 237). Failure to reject the null hypothesis suggests that there is no need for structural modelling, but failure to reject it may or may not imply endogeneity. Only under very special conditions (see Geroski, 1982, 58, for example) in industrial economics will failure to reject be compatible with exogeneity. Hence, it is convenient to regard failure to reject as only indicative of exogeneity.

Using Durbin-Wu-Hausman tests some evidence of endogeneity (see upper part of Table 4) was found between $S=g(P)$ and $C=h(P) .{ }^{8}$ The relevant F statistics (and associated with probability values in brackets) are given in Table 4.

\section{[INSERT TABLE 4 NEAR HERE]}

This statistical evidence confirms our a priori reasoning. As a result, theoretical and statistical criteria can be invoked to support our system estimation. The BaseSalesRatio which dates from early in the life of the firm, and age, $A g e_{i}$, are predetermined and thus exogenous. Tests were performed for the exogeneity of the other variables in the system, see Table 3 for definitions. They were: the level of liabilities of the firm, Liabilities, the main market of the firm, MainMarket ${ }_{i}$, the organising capability of the firm, $\operatorname{OrgCap}_{i}$, the number of major rivals, Rival $_{i}$, and the level of product differentiation, ProdDiffi. Our tests led us to regard Liabilities, MainMarket $_{i}$ and Rival $_{i}$ as clearly exogenous. There was some evidence of

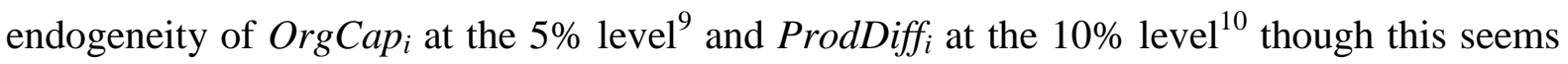
to be unidirectional in nature and small sample size limits the scope for exploring endogeneity further.

\subsection{System Estimation}

The available methods of estimating simultaneous equations vary, based on their use of information, and of different estimation techniques (e.g. maximum likelihood ${ }^{11}$, instrumental variables). Single equation methods, like two stage least squares (2SLS), and 
limited information maximum likelihood (LIML), estimate the model parameters of each equation at a time, whereas full-system estimators, like three stage least squares (3SLS) and full information maximum likelihood (FIML), estimate all the parameters jointly.

For comparative purposes, given the evidence of endogeneity, iterative three stage least squares (I3SLS) estimation was adopted. In the presence of endogeneity 3SLS, a full system estimator is likely to have an efficiency advantage over the single equation methods, such as 2SLS. We therefore only report in detail the results of iterative 3SLS because these results converge to those of FIML. The 2SLS estimates corrected for sample selection bias, not reported here but available from the authors, are largely similar to the I3SLS estimates except for the reduced significance of size in the performance equation, which suggests the efficiency advantage of using I3SLS. The work of Resende (2007) also illustrates the benefit of using 3SLS in another business economics model for which endogeneity is intrinsic.

Davidson and MacKinnon $(1993,234)$ state that it is generally desirable for a model to be somewhat over identified in order to ensure good finite sample properties, for the use of instrumental variable (IV) estimation, of which 3SLS is an example. The 'order condition' for identification therefore indicates that each of the three equations is over-identified, and that there are thirteen over identifying restrictions in total within the system. We conducted statistical tests of identification, which are reported in Section 5.

\section{Results}

To examine whether there are tradeoffs between firm size, competitive strategy and performance for our sample of long-lived firms we estimated the system of structural equations (4)-(6) using I3SLS estimation (Column I, Table 5) and using I3SLS instrumental variable method with a correction for sample selection bias $(N=186)\left(\right.$ Column II, Table 5) ${ }^{12}$. To correct for sample selection bias we used the approach of Koski and Kretschmer (2005). In Table 5, the estimated coefficients for equations (4), (5) and (6) and their elasticities at the means (in Column III) are reported. The t-values are in brackets. The selection equation is 
given in Note (b) of Table 5 and is a binary probit with variables for sector, full time and part time employees, start-up year and start-up sales, etc. The latter (StSales) is the most significant predictor of survival. The inverse Mills ratio $(\lambda)$ was found to be significant, when included in the performance equation (4) but not in the size and competitive strategy equations (5) and (6) respectively. This is in accord with Pfaffermayr (2007): it is important to account for sample selection when examining the size/performance trade-off. Our key estimates of the Size, competitive Strategy and Performance relations, corrected for sample selection bias are discussed below (Subsections 5.1 - 5.2). The robustness of our estimates, across both estimation techniques and four dimensions of performance, are discussed in Subsection 5.3. Finally, patterns of adjustment of Size, competitive Strategy and Performance within the model are examined in Subsection 5.4.

\subsection{Equation Estimates}

\section{[INSERT TABLE 5 NEAR HERE]}

Our estimates suggest the robustness of our findings across the Performance and Size equations, under both estimation techniques ${ }^{13}$. These estimates indicate that a trade-off indeed exists between firm size and performance. For our I3SLS estimates corrected for sample selection (Column II, Table 5), we see that Size has a significant negative influence on Performance, $P=f(S), f^{\prime}<0$ and vice versa, $S=g(P), g^{\prime}<0$. We need to ask why an increase in size, here measured by full-time equivalent employees, reduces the performance of the small firm. It is likely that these reductions in performance arise from a reduction in base sales ratio. This could be because there are increased costs associated with hiring more employees, with rising effort being expended in recruiting and training new staff. Thus, the firm sacrifices increases in profits or performance to grow. Viewed the opposite way, the performance equation suggests that reductions in firm size lead to increases in performance. As the firm reduces in size, ceteris paribus, performance increases, due to increased efficiencies (observed as an increased base sales ratio caused by the substitution of capital for 
labour and a leaner cost base), and a relative increase in the human (as well as physical) capital at work in the firm. Thus, by becoming a leaner organisation, the performance prospects of the firm are promoted. However, one would expect there to be diminishing returns to a strategy of this sort. At the limit, one-man outfits will find it difficult to compete in the same league as dominant players in the market unless their goods are very specialised (i.e. niche products). Certainly, if we assume that the goal of entrepreneurs is to raise their firm's performance, our trade-off relationship suggests that downsizing may be the principal way of improving performance.

The properties of the behavioural relation between the competitive strategy of the firm and performance are less clear. That the diversity of competitive strategy has a positive and significant effect on performance, see our estimate of equation (1) in Table 5, is consistent with the work of Claver-Cortés, Pertusa-Ortega, Molina-Azorín (2012), who find that hybrid competitive strategies influence performance positively. In our estimates of equation (3), the coefficient on performance is negative in sign (suggesting a trade-off), but is insignificant, at least at usual levels of significance. Causality is perhaps unidirectional, i.e. $P=f(S, C)$ but $C \neq g(P)$. That is, the competitive strategy of the firm has a significant positive influence on performance, but its performance does not significantly influence the diversity of the competitive strategy, $C=g(P)$. If again here we assume that the goal of the owner manager is to raise performance, the model points to improvements in performance if the firm reduces its size and competes strongly, using a wide variety of strategies.

\subsection{Elasticities}

We now examine each equation's elasticities at the mean, for our I3SLS estimates, corrected for sample selection bias. These are presented in Column III of Table 5. We now focus more on the quantitative impact of variables, rather than on their significance per se. In the performance equation a $1 \%$ increase in firm size leads to a $0.04 \%$ fall in performance and visa versa. Thus, increases in the size of the firm reduce its performance, but the impact is 
small. By contrast, the competitive strategy, $C_{i}$, has the largest impact on performance. A $1 \%$ increase in the competitive strategy of the firm leads to a $0.13 \%$ increase in performance. Should a firm be operating in an industry which is subject to technical change, $\left(\right.$ TechnicalChange $_{i}$ ) this experience has a significant positive effect (see Table 5) on performance and its impact is a quite large (elasticity is $0.12 \%$ ). Thus industry level technical change seems to have an important effect on promoting the performance of the firm.

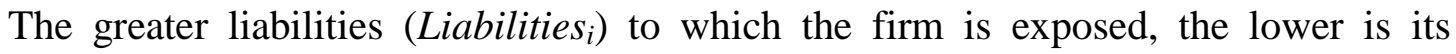
performance though this effect is not significant. A $1 \%$ increase in the liabilities of the average firm lowers performance by $0.03 \%$. Power and Reid (2005), also using a Scottish sample of typically small firms, find that gearing was insignificant in explaining long run survival. Similarly, Nunes, Goncalves and Serrasqueiro (2013) find that cashflow and debt are of greater relative importance for growth in young SMEs than for growth in more mature SMEs. The optimal strategy for highly geared small firms is to retire debt early in its lifecycle if equity finance is a cheaper source of finance, see Reid (2003). La Rocca, La Rocca and Cariola (2011) show how mature stage firms re-balance their capital structure substituting debt for internal capital.

The geographic extent of the firm's main market (MainMarket ${ }_{\text {) }}$ had a positive effect on firm performance, but this effect was not significant. The less the dependence on local markets, or put another way, the greater is the market's extent, the greater is the performance of the firm, other things being equal. However, Reid (2001) found that unless small firms start with marketing intentions which are explicitly aimed at national or international markets, they will never make this their main market, which perhaps may explains why this effect is insignificant. Corroborating this, Hallenstein (2005) finds that small firms have a narrow range of opportunity advantages for internationalisation. 
The effect of age $\left(A g e_{i}\right)$ on performance was also insignificant. Performance is seen to be a monotonically decreasing, convex function of age. There is therefore some suggestion that, as the firm gets older, its performance falls, but at a decreasing rate. This is a plausible result, in that, if performance fell at an increasing rate the long run survival prospects of these mature firms would be poor. Such an effect would not encourage the continuous investment in these firms which we have observed.

In the size equation, (middle equation in Table 5) performance had the largest impact on size. A $1 \%$ increase in performance leads to as much as a $10 \%$ fall in size (as measured by full-time equivalent employment). This effect is of considerable magnitude compared to the inverse influence of size on performance (elasticity of just $-0.04 \%$ ) in the first equation. This finding demonstrates why there is a tendency for these mature firms to reduce their headcount and to become leaner, to gain further improvements in performance. Here also, a firm operating in an industry, which is subject to technical change, experiences a significant positive effect on firm size (elasticity is $1.2 \%$ ). In response to great technical change in the industry the firm grows in size. Other things being equal, greater headcount is encouraged in response to technical change. Thus, the firm may also need to increase its human capital as it becomes more technologically intensive e.g. more skilled operatives to operate more complex machines or systems.

The effect of base sales ratio (BaseSalesRatio ${ }_{i}$ ), early in the life of the firm, on size was negative, but not significant. Firms, which generate more sales per fulltime equivalent employees, are more operationally efficient. Greater operational efficiency earlier in the life of the firm indicates a superior performer at this stage. Superior performers would be expected to grow in size. This may not be the case however, as firms grow faster in size earlier in their lifecycle, than in the latter part of their life. Thus this finding is indicative of early lifecycle effects in the base sales ratio. Younger and typically small firms grow faster, in response to increases in base sales ratio, than do mature firms. It had the lowest influence 
on size (elasticity is $-0.10 \%$ ). The organising capability of the firm, $\operatorname{OrgCap}_{i}$, had a positive and significant effect on the size of the firm at the $10 \%$ level. A $1 \%$ increase in organising capability of the firm raises firm size by $0.72 \%$. This result is consistent with the discussion of Ghoshal, Hahn and Moran (2000) on administrative reorganisation. To engage in a larger number of functional activities, a greater division of labour is required.

In the competitive strategy equation (equation 3 ) performance had a negative and insignificant effect on firm's competitive strategy where here this is measure of the diversity of competitive strategy. This is not surprising, as many factors other than performance may be determining the size, or scope, of the firm's competitive strategy. Higher levels of product differentiation had a positive and significant effect on the dimensions of the competitive strategy of the firm. The size of the elasticity of this effect was 0.34. To the extent that product heterogeneity $(\operatorname{ProdDiff} i)$ confers local monopolistic advantages on the firm, it increases the dimensions on which the firm competes to protect these advantages. This finding supports evidence that firms usually seek to cultivate mild forms of product differentiation, especially by customer service and delivery (Reid, 1993). However, it must be borne in mind that strongly differentiated products can only be sold in very limited niche markets, especially if they are constructed on a customer specified basis. The greater the competitive pressure in the market, as measured by the count of the number of rivals $\left(\right.$ Rival $\left._{i}\right)$, the smaller the number of dimensions of competitive strategy of the mature firm. Thus as the market approaches a perfectly competitive market the mature firm competes on less dimensions. The size of this impact is small relative to that of the level of product differentiation (the elasticity is just -0.04).

\subsection{Diagnostics}

The overall model significance and the individual coefficient significance were acceptable (at standard prob levels) and were also robust across the two estimation techniques 
(see Columns I and II, Table 5). The system $\mathrm{R}^{2}$ measure, $\tilde{R}^{2}$, was high at 0.8325 for the I3SLS estimates. ${ }^{14}$ A likelihood ratio test of the hypothesis that all the slope coefficients were equal zero in the I3SLS regression was rejected. The Chi-square statistic ${ }^{15}$ of 112.56 was greater than 31.32 critical value at an $\alpha$ level of $5 \%$. Thus the indications of $\tilde{R}^{2}$ measure are vindicated. A Breusch-Pagan Lagrange multiplier test for diagonality of the covariance matrix was rejected [Chi-square $(3 \mathrm{df}, \alpha=5 \%$.) of $23.045>12.84] .{ }^{16}$ This confirms that an equation-by-equation application of least squares estimation would have been inappropriate, and confirms the value of our seeking full system methods to estimate the structural equations of the model.

A test of the number of over identifying restrictions in our model can be conducted using the following likelihood ratio test statistic $2 *\left[\operatorname{Ln} L_{r}-\operatorname{Ln} L_{u}\right]$ where $\operatorname{Ln} L_{r}$ is the $\log$ likelihood from the restricted reduced form and $\operatorname{Ln} L_{u}$ is the log-likelihood from the unrestricted reduced form obtained by SUR regression using ML estimation. The $\chi^{2}$ test statistic for the 13 over-identifying restrictions was equal to $2 *[-558.894-(-565.2945)]=$ $2 *(6.4005)=12.801$, which is much smaller than the $0.05(0.01)$ chi-square critical value of 22.36 (27.688), suggesting that the over-identifying restrictions are consistent with the data (see Berndt, 1991, 554). Thus, the model seems robust across the two system estimation techniques we used.

In Table 6 we present I3SLS estimates of the model (corrected for sample selection) for a decomposition of four dimensions of our performance indicator (viz. internal, environment, finance and strategy). This is a severe test of robustness. To do this we summed the self-assessed ratings of items underlying each separate dimension of performance normalised as described above to take account of those items that were 'not applicable'. Thus we obtained four decomposed performance measures: (1) internal (viz. operational, skills, monitoring etc.); (2) environmental (viz. competition, access to buyers, 
substitutes, new entrants etc.); (3) financial (viz. cashflow, debt, credit policy, capital requirements etc.) and (4) strategic (viz. quality, cost control, market positioning, diversification etc.) performance scores. We observe from Table 6 that re-estimating our model using separately each of these four decomposed performance scores, rather than the overall scores, nevertheless yields remarkably similar results. This strongly confirms the robustness of our model. We note the consistency of our findings in these decomposed cases. Thus, Size largely has a negative and significant influence on each of these four decompositions of performance and these in turn jointly have a negative and significant influence on Size. The diversity of competitive strategy has a positive and significant effect on each decomposed dimension of performance. The environmental dimension of performance has jointly a negative and significant influence on diversity of competitive strategy which adds a new insight to our analysis, deriving from our decomposition of the overall performance index. The next subsection analyses the adjustment path of the behavioural relation between size, dimensions of competitive strategy and the multidimensional measure of performance.

\subsection{Adjustment Paths}

The final interpretation of our estimated model, of equations (4) to (6), examines the relationship between its endogenous variables: firm Size, competitive Strategy and Performance. If all its exogenous variables are assigned their mean values, the linear functions for the performance and size equations can be represented in a two-dimensional graph (see Figure 2). The stability of the model, and how it adjusts to equilibrium (see Figure 3) can then be examined.

Using the coefficients from the I3SLS estimates (corrected for selectivity) (see Table 5, Column II) with exogenous variables assigned to their mean values, functions (4) and (5) can be expressed as are follows: 
Performance $_{\mathrm{i}}=\quad 61.3907 \quad-0.2141$ Size $_{\mathrm{i}} \quad+1.9581$ Strategy $_{\mathrm{i}}$

Performance $_{\mathrm{i}}=70.28 \quad-0.2141$ Size $_{\mathrm{i}}$

Size $_{\mathrm{i}}=\quad 146.4868 \quad-1.9724$ Performance $_{\mathrm{i}}$

Where the required equation (7a) is obtained from (7), by assigning Strategy to its mean value. We graph equations 7(a) and (8) in Figure 2. Solving them for model's equilibrium values $(13.617,67.365)$ for Size and Performance. These magnitudes are close to the mean values for size and performance in the sample, namely 13.6508 and 67.3467 (see Table 3). We further note that the intersection of the equations (E) finds a stable equilibrium point. ${ }^{17}$ Thus starting from a performance level of, say, 70.3 on the vertical axis of Figure 2 a convergent path to the equilibrium point $E$ can be traced. Similarly, starting from a size of 18 full-time equivalent employees on the horizontal axis of Figure 2 another convergent path to $E$ can be traced. As $E$ is close to the relevant mean size and performance values in the sample, we confirm our typical mature firms are indeed approaching an equilibrium point. The magnitude of the adjustments for size are relatively larger than for performance. In response to increases in performance, there is a strong tendency for the mature firm to adjust downwards in size. That is, to improve its performance the firm needs to become leaner: of a more efficient size. Thus the trade-off between firm size and performance implies that there is a strong performance driven effect to remain small or to reduce in size. We now turn to the effect of competitive strategy on this trade-off.

\section{[INSERT FIGURES 2 AND 3 NEAR HERE]}

Figure 3 illustrates a shift in the performance function as a result of a change in the competitive strategy variable. If the firm increases the diversity of its competitive strategy (seen within this framework as a one unit increase in the count of dimensions of competitive 
strategy) the performance function shifts to the right and a new equilibrium point $E^{*}$ is reached where $E^{*}$ represents higher values of performance (71) and lower values of firm size (7). The magnitude of this increase in performance could be reduced if improvements in performance had a strong feed-back effect on the diversity of the firm's competitive strategy. However this effect was insignificant across both system estimation techniques and therefore has little impact here. In essence, Figure 3 suggests that the long run performance prospects of these mature firms can be promoted through further expansion of the dimensions by which they compete. Competing on a more diverse range of attributes of the likes of the firm's product, price, service etc. can enable it to achieve a higher equilibrium performance. This perhaps explains why small firms usually seek to cultivate numerous forms of product differentiation, especially by customer service and delivery etc. This implies clever use of niche markets, especially those that allow the delivery of goods or services on a bespoke basis. Further, economies of scope may exist for these firms, in the pursuit of these strategies in more localised or niche markets, Reid (1993).

\section{Discussion}

Contrary to Lee (2009) who finds a positive relationship between size and performance for large publically traded companies, for our typically small independent firms we find evidence of a trade-off between the firm's size and performance. By implication, the entrepreneur can raise performance over time by improving the efficiency of its labour-force. Typically this involves an increase in human capital of the 'core' workforce. The substitution of capital (including human capital) for standard labour inputs is another potential source of efficiency gain with consequences for firm size, see Aquilina, Klump and Petrobelli (2006). Our evidence suggests there are powerful equilibrating forces encouraging such actions.

The mean (and, in brackets, median) levels of employment of our firms: at start-up; after 5 years of trading; after 10 years of trading; and at our last interview, were 3.6 (2), 8.5 (5), 11.8 (6) and $13.6(7)$, respectively. This suggests a moderate growth in headcount over a 
long period of time. However, looking at the mature phase of our firms, a paired-sample T test for equality of the mean number of employees after ten years of trading and the mean number of employees at the times of final interview could not be rejected for the firms that survived $(\mathrm{T}=-0.274, \mathrm{df}=54$, probvalue $=0.785)$. The same test for equality of the mean number of employees after five years of trading and the mean number of employees at the times of final interview was rejected for the firms that survived $(\mathrm{T}=-2.350, \mathrm{df}=53$, probvalue $=0.023)$. Briefly, growth tends to occur early in the life-cycle. This suggests that improving the efficiency of labour (and consequentially restraining headcount) as the firm matures is important to sustaining its existence and improving its performance.

Focusing on the percentage of firms which have downsized in terms of employment, we find two percent of firms downsized in the first five years of trading. The percentage of firms downsizing however increased over time. Seventeen percent of firms downsized between 5 and 10 years of trading and 25 percent of firms downsized after that period, with a further $33 \%$ staying the same size after that period. Thus as suggested above there is evidence of restraint on the growth of headcount, or even downsizing, as the firm matures. There are many cases in the sample. Two examples illustrate this: (1) A manufacturer located near Dundee in Scotland, producing large bulk bag or sacks used to package heavy, irregular industrial or agricultural products (e.g. coal, chopped logs, turnips), downsized its manufacturing of bulk bags, and instead became chiefly a merchandiser of similar bags produced more cheaply in Asia. Forty employees were made redundant over time to enable the firm to become more competitive in the global market place. (2) A light manufacturer located near Edinburgh also downsized, but this time it was a consequence of investment in a new technology, which enabled the firm to be a low cost leader of bespoke plastic injection mouldings. Capital was substituted for the labour input. The latter raised the marginal productivity of the capital and labour employed by the business. 
We know that lean organisations can be 'beautiful' for many reasons. Certainly, they can respond faster to environmental change and to new opportunities in the market given their relatively flat organisational structures, Carlsson (1989). The advantages of greater market power and access to economies of scale and scope garnered by increased size are not necessary conditions for efficient production. In fact, small firms have generally been found to be more productive than large firms, see De and Nagari (2014), Nguyen and Rezuek (1991). Furthermore, the rate of profitability is not necessarily higher for larger enterprises. Indeed, the opposite maybe true. Dhawan (2001) found that profit rates and levels of efficiency for large US firms are much smaller than those of small firms. This higher level of reward for smaller enterprises is arguably consonant with the increased risk of failure that smaller sized firms face.

We also find that to attain higher equilibrium values of performance the firm needs to adopt a more varied competitive strategy, for example, by increasing the extent of product differentiation. It is known that such a differentiation strategy enables less efficient firms to survive, see Syverson (2004), which may help such firms to sustain their small scale existence. While the evidence for an endogenous relationship between competitive strategy and performance is equivocal in our study, further micro-micro studies of this nature, which explore sources of endogeneity within a simultaneous equations framework, may yet prove a fruitful area of research in explaining how firms sustain their small scale existences. Other inherent attributes of the firm could explain the tendency of the firm to remain small. Candidates for this include: the size of the market for its product (e.g. local, regional etc.); the firm's organisational capability; the extent of customisation of products; and potential risks to the income of the owner manager (e.g. as a result of cash-flow difficulties, or overinvestment). A large scale longitudinal study could be used to explore the joint influence of such effects, in a more encompassing model. 
Generally, we find that a large proportion of our sample of firms are not 'scaleable'. This should be recognised by business educators and policy makers. Proportionately few firms will grow to be large firms. Policies and strategies to promote longevity should not solely focus on the few 'gazelles' which enjoy extremely high levels of growth, but should focus more on the bedrock of small firms who tend to remain small throughout their lives, such as the typical firms in our sample, see Beesley and Hamilton, (1984). A highly skilled, flexible labour market may aid long-lived firms in their efforts to sustain their small scale existences, given the observed size-performance trade-off relationship. Awareness of the means to increase input resource utilisation is also important for the productivity of the firm. Examples of business trends in this direction include automation, networking and strategic alliances in delivering aspects of the service, shared facilities, franchising etc. The latter limit the size of the firm, and would arguably raise the long run performance of the small firm. To illustrate, Rosa and Hanoteau (2012) explain the trend of even small firms to downsizing in recent decades by the new abundance of information - the ICT revolution.

\section{Conclusions}

This paper examines behavioural relations between firm size, the firm's competitive strategy and the performance of the long-lived firm in Scotland. The latter two variables are measured in novel ways. In this work, we find there is a strong tendency for the firm to remain small. The reasons are twofold. First, as a trade-off exists between firm size and performance, the mature firm must be lean, and more efficient, if it is to survive. Second, to attain higher equilibrium values of performance, a more varied competitive strategy needs to be adopted. This can be achieved through producing customised or specialist products, but also through increasing the aggressiveness of competitive strategy to defend market niches (e.g. by raising advertising and marketing efforts). The performance of firms is linked to product differentiation, as typically small firms are niche players. The tendency in this instance is to become more specialised and localised and to seek economies of scope for 
improving the prospects of the firm. Such firms must also be proactive in defending their niches in the market. Acting in these ways, entrepreneurs can have a positive influence on the long run performance of their firms.

\section{Acknowledgements}

This research was undertaken with the generous support of Enterprise Ireland, to whom the authors make grateful acknowledgement. We should also like to thank the many ownermanagers of small firms in Scotland, who gave generously of their time, to allow us to collect high quality data in the field. Finally, the work on which this paper is based has benefitted from the comments of numerous people, in conferences (e.g. Scottish Economic Society, Irish Economic Society, Royal Economic Society, European Association for Research in Industrial Economics, European Economic Society), seminars and workshops (e.g. Universities/Colleges of Aberdeen, Babson, Barcelona, Birmingham, Copenhagen, Cork, Durham, Lancaster, Limerick, Nice, St Andrews, Strathclyde, Warwick), in workshop and research centre discussions (e.g. ZEW Mannheim, CREM Caen) and in private correspondence. They are all thanked for their inputs, but absolved of any responsibility for the form this paper takes.

\section{References}

Almus, Matthias. 2002. "What Characterises a Fast-Growing Firm?” Applied Economics 34 (12): 1497-1508.

Aloysius, John, Cary Deck, and Amy Farmer. 2012. "A Comparison of Bundling and Sequential Pricing in Competitive Markets: Experimental Evidence.” International Journal of the Economics of Business 19 (1): 25-51.

Anthony, Ariel, Steven B. Caudill, and Franklin G. Mixon Jr. 2012. "The Political Economy

of Women's Professional Basketball in the United States: A Structure-ConductPerformance Approach.” Theoretical and Applied Economics 19 (11):107-126. 
Aquilina, Matteo, Rainer Klump, and Carlo Petrobelli. 2006. "Factor Substitution, Average Firm Size and Economic Growth.” Small Business Economics 26 (3): 203-214.

Arrigheti, Alessandro, and Andrea Lasagni. 2013. "Assessing The Determinants of HighGrowth Manufacturing Firms in Italy." International Journal of the Economics of Business 19 (22): 285-314.

Bain Joe S. 1951. "Relation of Profit Rate to Industry Concentration: American Manufacturing, 1936-1940.” Quarterly Journal of Economics 65 (3): 293-324.

Barber, John, Stanley Metcalfe, and Mike Porteous. 1989. Barriers to Growth in Small Firms: Small Business Series. London: Routledge.

Barbosa, Natalia, and Vasco Eiriz. 2011. "Regional Variation of Firm Size and Growth: The Portuguese Case." Growth and Change 42 (2): 125-158.

Barringer, Bruce R., Foard F. Jones, and Donald O. Neubaum. 2005. “A Quantitative Content Analysis of the Characteristics of Fast Growth Firms and their Founder's." Journal of Business Venturing 20 (5): 663-687.

Beccarello, Massimo. 1997. “Time Series Analysis of Market Power: Evidence from G-7 Manufacturing.” International Journal of Industrial Organisation 15 (1): 123-136.

Beesley, M. E., and R. T. Hamilton. 1984. "Small Firms Seedbed Role and the Concept of Turbulence.” Journal of Industrial Economics 33 (2): 217-213.

Berndt, Ernest. R. 1991. The Practice of Econometrics: Classic and Contemporary. United States: Addison-Wesley Publishing Company.

Bonaccorsi, A., and S. Giannangeli. 2010. "One or More Growth Processes? Evidence from New Italian Firms.” Small Business Economics 35 (2): 137-152

Cameron, A. Colin, and Pravin K. Trivedi. 2005. Microeconometrics: Methods and Applications. New York: Cambridge University Press.

Carlsson, Bo. 1989. "Flexibility and the Theory of the Firm." International Journal of Industrial Organization 7 (2): 179-204. 
Carmignani, Fabrizio. 2011. “The Making of Pro-Poor Growth.” Scottish Journal of Political Economy 58 (5): 656-684.

Chen, Ming-Yuan. 2006. "Managerial Ownership and Firm Performance: An Analysis Using Switching Simultaneous-Equations Models.” Applied Economics 38 (2): 161-181.

Chen, Yi-Min, De-Hsin Yang, and Feng-Jyh Lin. 2012. "Does Technological Diversification Matter to Firm Performance? The Moderating Role of Organizational Slack.” Journal of Business Research 66 (10): 1970-1975.

Chrisman, James. J., Alan Bauerschmidt, and Charles W. Hofer. 1998. “The Determinants of New Venture Performance: An Extended Model.” Journal of Business Venturing 23 (1): 5-29.

Claver-Cortés, Enrique, Eva M. Pertusa-Ortega, and José F. Molina-Azorín. 2012. "Characteristics of Organizational Structure Relating to Hybrid Competitive Strategy: Implications for Performance.” Journal of Business Research 65 (7): 993-1002.

Coad, Alex, and Tamvada Jaganaddha. 2012. "Firm Growth and Barriers to Growth Among Small Firms in India.” Small Business Economics 39 (2): 383-400.

Colombo, Massimo G., Marco Delmastro, and Luca Grilli. 2004. "Entrepreneurs' Human Capital and the Start-up Size of New Technology-Based Firms.” International Journal of Industrial Organization 22 (8-9): 1183-1211.

Covin, Jeffrey G., and Dennis P. Slevin. 1989. "Strategic Management of Small Firms in Hostile and Benign Environments.” Strategic Management Journal 10 (1): 75-87.

Cronbach, Lee J. 1951. "Coefficient Alpha and Internal Structure of Tests." Psychometrica 16 (3): 297-334.

Davidson, Russell, and James G. MacKinnon. 1993. Estimation and Inference in Econometrics. Oxford: Oxford University Press.

Davidsson, Per, Leona Achtenhagen, and Lucia Naldi. 2010. Small Firm Growth. Hanover USA: Now Publishers. 
De, Prabal K., and Priya Nagari. 2014. "Productivity and Firm Size in India." Small Business Economics 42 (4): 891-907.

Delorme, Charles D., David R. Kamerschen, Peter G. Klein, and Lisa F. Voeks, .2002. "Structure Conduct, Performance: A Simultaneous Equations Approach." Applied Economics 34 (17): 2135-2141.

Delmar, Frédéric, Per Davidsson, and William B. Gartner. 2003. "Arriving at the High Growth Firm.” Journal of Business Venturing 18 (2): 189-216.

DeVellis, Robert F. 1991. Scale Development: Theory and Applications. Vol. 26 of Applied Social Research Methods Series. London: Sage Publications.

Dhawan, Rajeev. 2001. "Firm Size and Productivity Differential: Theory and Evidence From a Panel of US Firms.” Journal of Economic Behaviour and Organization 44 (3): 269-293.

Dickey, Heather, Verity Watson, and Zangelidis Alexandros. 2011. “Job Satisfaction and Quit Intentions of Offshore Workers in the UK North Sea Oil and Gas Industry.” Scottish Journal of Political Economy 58 (5): 607-633.

Dosi, Giovanni, Alfonso Gambardella, Marco Grazzi, and Luigi Orsenigo. 2008. "Technological Revolution and the Evolution of Industrial Structures: Assessing the Impact of New Technologies Upon the Size and Boundaries of Firms.” Capitalism and Society 3 (1): 1-37.

European Commission (2003) "Commission Recommendation of 6 May 2003 Concerning The Definition Of Micro, Small And Medium-Sized Enterprises." Official Journal of the European Union, L 124/36.

Farinas, José C., and Sonia Ruano. 2004. “The Dynamics of Productivity: A Decomposition Approach Using Distribution Functions.” Small Business Economics 22 (3-4): 237-251. 
Feldman, Jonathan M., and Magnus Klofsten. 2000. "Medium-Sized Firms and the Limits to Growth: A Case Study in the Evolution of a Spin-off Firm.” European Planning Studies $8(5): 631-650$.

Francis, Kimesha, Henry Ralston, Jackson Anetheo, Shaneka Stewart, and Darron Thomas. 2011. "Small Firms, their Growth and Product Differentiation." International Journal of Business and Social Science 2 (19): 86-95.

Geroski, Paul A. 1982. "Simultaneous Equation Models of the Structure Performance Paradigm.” European Economic Review 19 (2): 145-158.

Ghoshal, Sumantra, Martin Hahn, and Peter Moran. 2000. "Organising for Firm Growth: The Interaction Between Resource Accumulating and Organising Process". In Competence, Governance and Entrepreneurship: Advances in Economic Strategy Research, edited by Foss, Nicolai and Mahnke Volker, 146-167. Oxford: Oxford University Press.

Goldberg, Eskil, Leo A. Grünfeld, and Gabriel R.G. Benito. 2008. "The Performance Differential Between Private and State-Owned Enterprise: The Roles of Ownership, Management and Market Structure.” Journal of Management Studies 45(7): 1244-1273.

Greene, William H. 2011. Econometric Analysis. 7th ed. Boston: Prentice Hall.

Hallenstein, Heinz. 2005. "Determinants of International Activities: Are SMEs Different?" Small Business Economics 24 (5): 431-450

Heneman, Robert L., Judith W. Tanksy, and Michael S. Camp. 2000. "Human Resource Management Practices in Small Medium Sized Enterprises: Unanswered Questions and Future Research Perspectives.” Entrepreneurship: Theory and Practice 25 (1): 53-74.

Henrekson, Magnus, and Dan Johansson. 1999. "Institutional Effects on the Evolution of the size Distribution of Firms.” Small Business Economics 12 (1): 11-23

Henrekson, Magnus, and Dan Johansson. 2010. “Gazelles as Job Creators: A Survey and Interpretation of the Evidence.” Small Business Economics 35 (2): 227-244. 
Hmielski, Keith M., and Robert. A Baron. 2009. "Entrepreneurs Optimism and New Venture Performance: A Social Cognitive Perspective.” Academy of Management Journal 52 (3): 473-488.

Hsieh, Chang-Tai, and Peter J. Klenow. 2012. "The Lifecycle of Plants in India and Mexico.” NBER Working Papers 18133. National Bureau of Economic Research, Inc.

Huggins, Robert. 2011. "The Growth of Knowledge-Intensive Business Services: Innovation, Markets and Networks.” European Planning Studies 19 (8): 1459-1480.

Illucea, Manuel, and Juan. A. Lafuente. 2003. "Productivity and Scale Effect in Closely Related Firms.” International Small Business Journal 21 (2): 161-180.

Jans, Ivette, and David I. Rosenbaum. 1996. "Multimarket Contact and Pricing: Evidence from the US Cement Industry.” International Journal of Industrial of Organization 15 (3): 391-412.

Jacobsen, Lowell R. 1986. "Entrepreneurship and Competitive Strategy in the New Small Firm: An Empirical Investigation.” PhD Diss., University of Edinburgh.

Kiviluoto, Niklas. 2013. "Growth as evidence of firm success: myth or reality?" Entrepreneurship and Regional Development: An International Journal 25 (7-8): 2013

Koski, Heli, and Tobias Kretschmer. 2005. "Entry Standards and Competition: Firm Strategies and the Diffusion of Mobile Technology." Review of Industrial Organization 26 (1): 89-113.

La Rocca, Maurizio, Tiziana La Rocca, and Alfio Cariola. 2011. "Capital Structure Decisions During the Lifecycle." Small Business Economics 37 (1): 107-130.

Lee, Jim. 2009. "Does Size Matter in Firm Performance? Evidence from US Public Firms" International Journal of the Economics of Business 16 (2): 189-203.

Leibenstein, Harvey. 1979. "A Branch of Economics is Missing: Micro-Micro Theory." Journal of Economic Literature 17 (2): 477-502. 
Leibenstein, Harvey. 1992. "Empirical Estimation and Partitioning of X-inefficiency: A Data Envelopment Approach." American Economic Review 82 (2): 428-433.

Leitner, Karl-Heinz, and Stefan Güldenberg. 2010. "Generic Strategies and Firm Performance in SMEs: A Longitudinal Study of Austrian SMEs." Small Business Economics 35 (2): 169-89.

Liu, Yi S., Xue F. Zhao, Yu P. Liao. 2013. "Market structure, ownership structure, and performance of China's construction industry." Journal of Construction Engineering and Management 139 (7): 852-857.

Lopez-Garcia, Paloma, and Sergio Puente. 2012. "What Makes a High-Growth Firm? A Dynamic Probit Analysis Using Spanish Firm-level Data." Small Business Economics 39 (4): 1029-1041.

Lotti, Francesca, Enrico Santarelli, and Marco Vivarelli. 2009. "Defending Gibrat's Law as a Long-Run Regularity.” Small Business Economics 32 (1): 31-44.

Lucas, Robert E. 1978. "On the Size Distribution of Business Firms." Bell Journal of Economics 9 (2): 508-523.

Luttmer, Erzo G.J. 2011. “On the Mechanics of Firm Growth.” Review of Economic Studies 78 (3): 1042-1068.

Mann, H. Micheal. 1966. "Seller Concentration, Barriers to Entry and Rates of Return in Thirty Industries, 1950-1960.” The Review of Economics and Statistics 48(3): 296-307 Mata Josè, Pedro Portugal, and Paulo Guimarães. 1995. "The Survival of New Plants: StartUp Conditions and Post-Entry Evolution.” International Journal Industrial Organization 13 (4): 459-482.

Mata, Josè, and Pedro Portugal. 1994. "Life Duration of New Firms". Journal Industrial Economics 42 (3): 227-245.

McDonald, James T., and Harry Bloch. 1999. "The Spillover Effects of Industrial Action on Firm Profitability." Review of Industrial Organization 15(2): 183-200. 
Mukhopadhyay, Arun, and Sal AmirKhalkhali. 2010. "Profitability Performance and Firm Size-Growth Relationship." Journal of Business and Economics Research 8 (9): 121126.

Nguyen, Sang V., and Arnold P. Rezuek. 1991. "Returns to Scale in Small and Large US Manufacturing Establishments: 1977-1982.” Small Business Economics 3 (3): 197-214.

Nunes, Paulo M., Marco Goncalves, and Zélia Serrasqueiro. 2013. "The Influence of Age on SMEs Growth Determinants: Empirical Evidence.” Small Business Economics 40 (2): 249-272.

Nunnally, Jum C. 1978. Psychometric Theory. New York: McGraw-Hill.

Ochsen, Carsten. 2011. "Subjective Wellbeing and Aggregate Unemployment: Further Evidence.” Scottish Journal of Political Economy 58 (5): 634-655.

Parker, Simon, David J. Storey, and Arjen Witteloostuijn. 2010. "What happens to gazelles? The Importance of Dynamic Management Strategy.” Small Business Economics 35 (2): 203-226.

Penrose, Edith T. 1959. The Theory of Growth of the Firm. Oxford: Basil Blackwell.

Petrakis, P. E. 1997. "Entrepreneurship and Growth: Creative and Equilibrating Events." Small Business Economics 9 (5): 383-402.

Pfaffermayr, Michael. 2007. "Firm Growth Under Sample Selection: Conditional $\sigma$ Convergence in Firm Size?” Review of Industrial Organization 31 (4): 303-328.

Pham, Peter, Jo-Ann Suchard, and Jason Zein. 2011. "Corporate Governance and Alternative Performance Measures: Evidence from Australian Firms." Australian Journal of Management 36 (3): 371-386.

Phillips, Almarin. 1976. "A Critique of Empirical Studies of Relations Between Market Structure and Profitability.” Journal of Industrial Economics 24 (4): 241-249.

Porter, Michael E. 1980. Competitive Strategy. New York: Free Press.

Porter, Michael E. 1985. Competitive Advantage. New York: Free Press. 
Power, Bernadette, and Gavin. C. Reid. 2005. "Flexibility, Firm-specific Turbulence and the Performance of the Long-Lived Small Firm." Review of Industrial Organization 26 (4): 415-443.

Reid, Gavin C. 1987. Theories of Industrial Organization. Oxford: Basil Blackwell.

Reid, Gavin C. 1993. Small Business Enterprise: An Economic Analysis. London: Routledge.

Reid, Gavin C. 1995. "Early Life-cycle Behaviour of Micro-Firms in Scotland." Small Business Economics 7 (7): 89-95.

Reid, Gavin C. 1998. “Limits to a Firm's Rate of Growth: The Richardsonian View and its Contemporary Empirical Significance. In Capabilities and Coordination: Essays in Honour of G.B. Richardson” edited by Loasby, Brian J. and Nicolai J. Foss, 243-260. London: Routledge.

Reid, Gavin C. 2001. "Flexibility in the Small Firm: The Dynamics of Market Repositioning and Scale Adjustment in the Early Stages of the Life Cycle." CRIEFF Discussion Paper Series No. 0105, Department of Economics, University of St. Andrews.

Reid, Gavin C. and Margo Anderson. 1992. “A New Small Firms Database: Sample Design, Instrumentation and Summary Statistics." CRIEFF Discussion Paper, Dept. of Economics, University of St. Andrews, No. 9207.

Reid, Gavin. C. 2003. "Trajectories of Small Business Financial Structure.” Small Business Economics 20 (4): 273-285.

Resende, Marcelo. 2007. "Structure, Conduct and Performance: A Simultaneous Equations Investigation for the Brazilian Manufacturing Industry.” Applied Economics 39 (7): 937942.

Richardson, George B. 1964. "The Limits to a Firm's Rate of Growth." Oxford Economic Papers 16 (1): 9-23.

Rogers, Mark, Christan Helmers, and Christoffer Koch. 2010. "Firm Growth and Firm Size, Applied Economics Letters 17 (16): 1547-1550. 
Rosa, Jean-Jacques, and Julien Hanoteau. 2012. "The Shrinking Hand: Why Information Technology Leads to Smaller Firms" International Journal of the Economics of Business 19 (22): 285-314.

Sahoo, Deepti, and Pulak Mishra. 2012. "Structure, Conduct and Performance of Indian Banking Sector." Review of Economic Perspectives 12(4): 235-264

Sandberg, William R., and Charles W. Hofer. 1987. "Improving New Venture Performance: The Role of Strategy, Industry, Structure and the Entrepreneur." Journal of Business Venturing 2 (1): 5-28.

Santarelli, Erico, Luuk Klomp, and Roy A. Thurik. 2007. “Gibrat's Law: An Overview of Empirical Evidence." In Entrepreneurship, Growth and Innovation: The Dynamics of Firms and Industries edited by Enrico Santerelli, New York: Springer.

Segarra, Agusti, and Teruel, Mercedes. 2014. "High Growth Firms and Innovation: An Empirical Analysis for Spanish Firms.” Small Business Economics DOI: 10.1007/s11187014-9563-7.

Setiawan, Maman, Grigorios Emvalomatis, and Alfons O. Lansink. 2013. "Structure, Conduct and Performance: Evidence from the Indonesian Food and Beverage Industry." Empirical Economics 45 (3): 1149-1165.

Shyu, Jonchi. 2006. "Family Ownership and Firm Performance: Evidence from Taiwanese Firms.” International Journal of Managerial Finance 7 (4): 397-411.

Singh, Ajit, and Geoffrey. Whittington. 1975. "The Size and Growth of Firms." The Review of Economic Studies 42 (1): 15-26.

Sivramkrishna, Sashi. 2014. "From Merchant to Merchant-Ruler: A Structure, Conduct, Performance Perspective of the East India Company’s History, 1600-1765." Business History 56 (5): 789-815.

Slater, Martin. 1980. "The Managerial Limitation to the Growth of Firms." Economic Journal 90 (3593): 520-528. 
Smith, Julia A. 1997. "Small Business Strategy: An Empirical Analysis of the Experience of New Scottish Firms.” PhD diss. University of Abertay.

Spulber, Daniel F. 2013. "Innovation Economics: The Interplay Among Technology Standards, Competitive Conduct and Economic Performance.” Journal of Competition Law and Economics 9 (4): 777-825.

Stam, Erik, and Karl Wennberg. 2009. "The Roles of RandD in New Firm Growth.” Small Business Economics 33 (1): 77-89.

Stam, Erik. 2010. "Growth Beyond Gibrat: From Growth Processes and Strategies.” Small Business Economics 35 (2): 129-135.

Steffens, Paul R., Per Davidsson, and Jason R. Fitzsimmons. 2009. "Performance Configurations Over Time: Implications for Growth- and Profit-oriented Strategies." Entrepreneurship: Theory and Practice 33 (1): 125-148.

Storey, David J. 1994. Understanding the Small Business Sector. London: Routledge.

Strotmann, Harald. 2007. “Entrepreneurial Survival.” Small Business Economics 28 (1): 87104.

Sutton, John. 1997. “Gibrat's Legacy.” Journal of Economic Literature 35 (1): 40-59.

Syverson, Chad. 2004. "Product Substitutability and Productivity Dispersion." The Review of Economics and Statistics 86 (2): 534-550.

Van der Stede, Wim A., Chee W. Chow, and Thomas W. Lin. 2006. "Strategy, Choice of Performance Measures and Performance.” Behavioral Research in Accounting 18 (1): 185-205.

Van Praag, Mirjam, and Jan S. Cramer. 2001. "The Roots of Entrepreneurship and Labour Demand: Individual Ability and Low Risk Aversion.” Economica 68 (269): 45-62.

Van Reenen, John. 2011. "Does Competition Raise Productivity Through Improving Management Quality?” International Journal of Industrial Organization 29 (3): 306-316. 
Wall, Toby D., Jonathon Michie, Malcom Patterson, Stephen J. Wood, Maura Sheehan, Chris W. Clegg, and Martin West. 2004. "On the Validity of Subjective Measures of Company Performance.” Personnel Psychology 57 (1): 95-118.

Wiklund, Johan, Per Davidsson, and Frédéric Delmar. 2003. "What do they Think and Feel About Growth? Expectancy - Value Approach to Small Business Managers' Attitudes Toward Growth.” Entrepreneurship: Theory and Practice 27 (3): 247-270.

Younsuk Park, Jaeun Shin, and Taejong Kim. 2010. "Firm Size, Age, Industrial Networking, and Growth: A Case of the Korean Manufacturing Industry" Small Business Economics 35 (2): 153-168.

\section{Appendix: Extract from the Survey Questionnaire [Online only]}

Responses to question 2.8.2 reproduced below from survey instrumentation were used in calculating our competitive intensity measure.

2.8.2 What form of competition is used in your principal market?

Price

Quality

Volume

After sales service

New product development

Advertising

Tying up suppliers

Delivery

Marketing

Other? (Please specify) 
Responses to question 4.1 reproduced from the survey instrumentation were used in calculating our performance index.

4.1 We'd like to know what has kept you in business down the years. Some things are good for business and some things are bad. What effect have the following had?

[Hand the respondent show card 4.1][The respondent should show with a cross whether the effect was good or bad.]

Suppliers

Growth

Competition

Buyer's willingness to pay

Customer loyalty

Access to buyers

Substitutes

New entrants

Technology

Rival's Innovation

Regulation

Cashflow

Debt

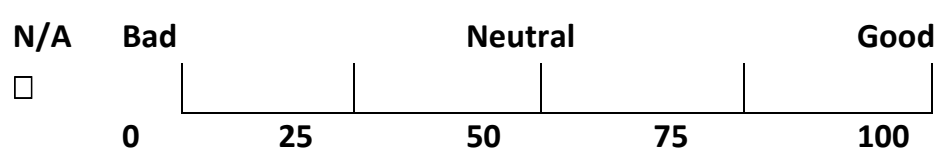

N/A Bad Neutral Good

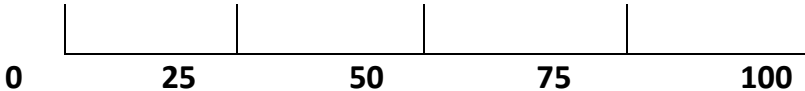

N/A Bad Neutral Good

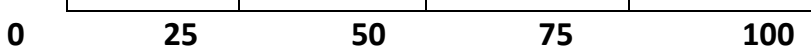

N/A Bad Neutral Good

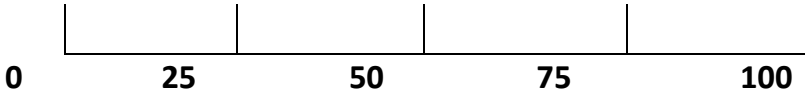

N/A Bad Neutral Good

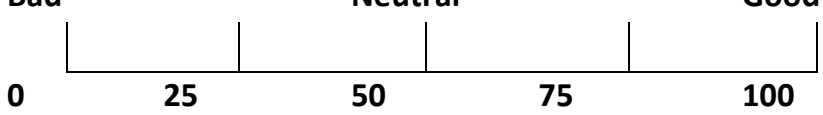

N/A Bad Neutral Good

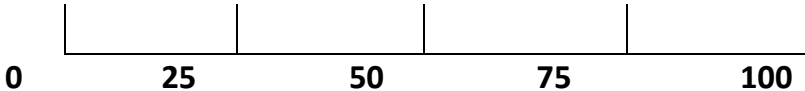

N/A Bad Neutral Good

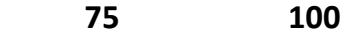

N/A Bad Neutral Good

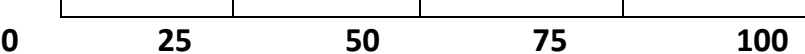

N/A Bad Neutral Good
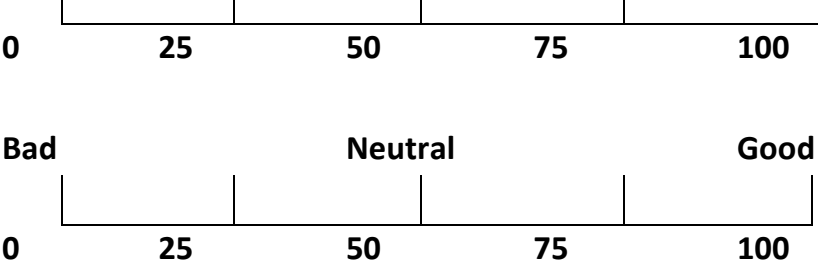

N/A Bad Neutral Good

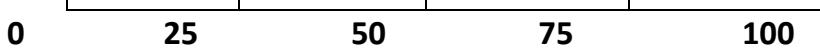

N/A Bad Neutral Good

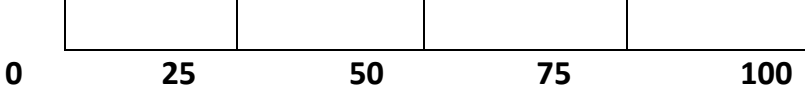

N/A Bad Neutral Good

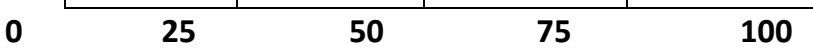


Credit Policy

Capital requirements

Market positioning

Location

Cost Control

Quality

Market research

Differentiation

Advertising

Product/Service Mix

Diversification

Operational efficiency

Skills

Monitoring

Filling product gaps
N/A Bad
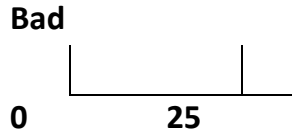

N/A Bad

Neutral

Good

0

Neutral
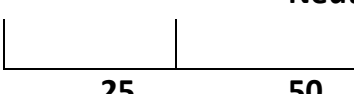

50

Neutral

N/A Bad

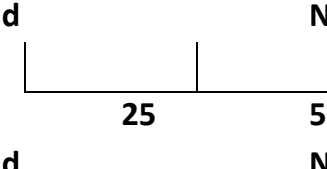

N/A Bad

Bad Neutral Good 100
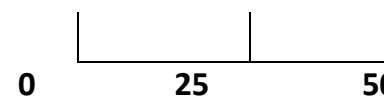

N/A Bad

Neutral

100

$$
\square
$$

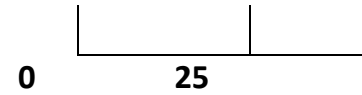

N/A Bad

Neutral

100

$\square$

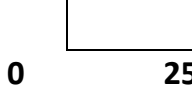

N/A Bad
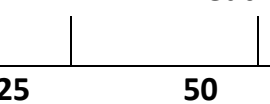

Good

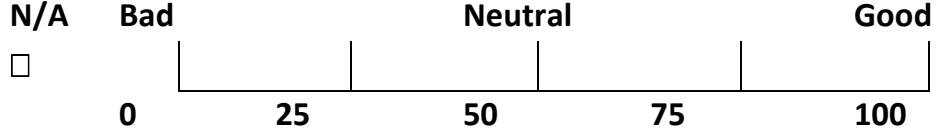

N/A Bad

Neutral

Good

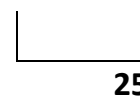

N/A Bad

Neutral Good

100

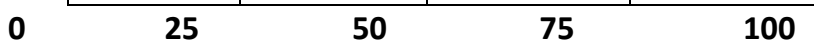

N/A Bad Neutral Good

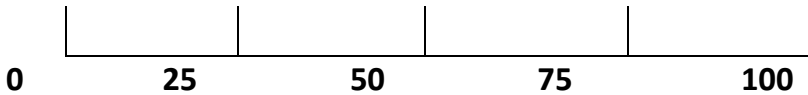

N/A Bad Neutral Good

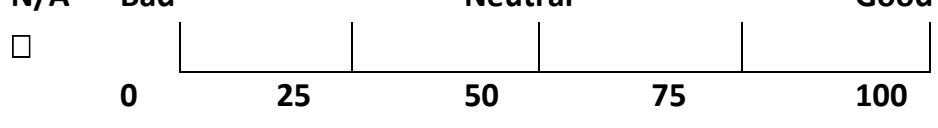

N/A Bad Neutral Good

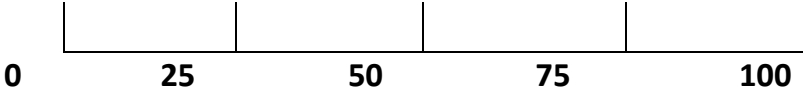

N/A Bad Neutral Good

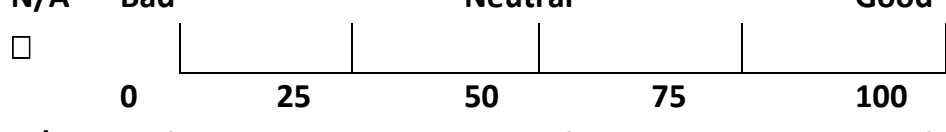

N/A Bad Neutral Good

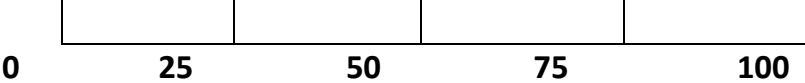

N/A Bad Neutral Good

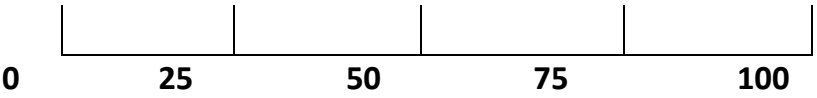

[Once the respondent has completed his/her reply retrieve the show card] 
Table 1. The construction of the sample

\begin{tabular}{||l|r|r|r|r|r|r||}
\hline $\begin{array}{c}\text { Numbers in Parent Sample } \\
\text { [First Interview] }\end{array}$ & \multicolumn{3}{c|}{$\begin{array}{c}\text { Eligible Firms } \\
\text { [Founded prior to 1991] }\end{array}$} & \multicolumn{2}{c||}{$\begin{array}{c}\text { Survivors } \\
\text { [Second Interview] }\end{array}$} \\
\hline Sample & Total & Survivors & $\begin{array}{c}\text { Non } \\
\text { survivors }\end{array}$ & Total & $\begin{array}{c}\text { Non } \\
\text { response }\end{array}$ & Interviewed \\
\hline Leverhulme (1985-1988) & 86 & 25 & 61 & 86 & 5 & 20 \\
\hline Telephone Survey (1991) & 160 & 50 & 57 & 107 & 20 & 30 \\
\hline Leverhulme (1994-1997) & 150 & 15 & 5 & 20 & 2 & 13 \\
\hline Total & $\mathbf{3 9 6}$ & $\mathbf{9 0}$ & $\mathbf{1 2 3}$ & $\mathbf{2 1 3}$ & $\mathbf{2 7}$ & $\mathbf{6 3}$ \\
\hline
\end{tabular}


Table 2. Sample composition

\begin{tabular}{|l|r|r|r|r|}
\hline \multirow{2}{*}{ Sample } & \multicolumn{2}{|c|}{$\begin{array}{c}\text { Extracted } \\
\text { Sample }\end{array}$} & \multicolumn{2}{c|}{$\begin{array}{c}\text { Interviewed } \\
\text { Survivors }\end{array}$} \\
\cline { 2 - 5 } & Manufacturing & Services & Manufacturing & \multicolumn{1}{c|}{ Services } \\
\hline Leverhulme (1985-1988) & 53 & 33 & 12 & 8 \\
& $(61 \%)$ & $(39 \%)$ & $(60 \%)$ & $(40 \%)$ \\
\hline Telephone Survey (1991) & 21 & 86 & 9 & 21 \\
& $(20 \%)$ & $(80 \%)$ & $(30 \%)$ & $(70 \%)$ \\
\hline Leverhulme (1994-1997) & 8 & 12 & 4 & 9 \\
& $(40 \%)$ & $(60 \%)$ & $(31 \%)$ & $(69 \%)$ \\
\hline Total & $\mathbf{8 2}$ & $\mathbf{1 3 1}$ & $\mathbf{2 5}$ & $\mathbf{3 8}$ \\
& $\mathbf{( 3 8 \% )}$ & $\mathbf{( 6 2 \% )}$ & $\mathbf{( 4 0 \% )}$ & $\mathbf{( 6 0 \% )}$ \\
\hline
\end{tabular}


Table 3. Variable definitions and summary statistics

\begin{tabular}{|c|c|c|c|c|c|}
\hline Variable & Definition & Mean & $\begin{array}{l}\text { Standard } \\
\text { Deviation }\end{array}$ & Minimum & Maximum \\
\hline Age & Age of firm, in years. & 25.5397 & 15.7284 & 10 & 90 \\
\hline FTemployees & Number of full-time employees at start-up. & 5.8438 & 8.8048 & 0 & 64 \\
\hline BaseSalesRatio & $\begin{array}{l}=\text { [Sales at first interview (1985 for Leverhulme 1985-1988, } 1991 \text { for } \\
\text { Telephone 1991, } 1994 \text { for Leverhulme 1994-1997) at } 2001 \text { prices]/ } \\
\text { [Employees at first interview]. }\end{array}$ & 113489 & 125103 & 1780 & 549577 \\
\hline Liabilities & $\begin{array}{l}=\sum f_{j} \text { where the } f_{j} \text { are counts of forms of debt used in the firm's principal } \\
\text { markets. }\end{array}$ & 1.8254 & 1.4429 & 0 & 4 \\
\hline MainMarket & $=1($ Local $),=2($ Regional $),=3($ Scottish $),=4($ British/International $)$. & 2.2698 & 1.2599 & 1 & 4 \\
\hline OrgCap & $=\sum f_{j}$ where the $f_{j}$ are the counts of activities performed in the firm in 2001. & 7.2381 & 2.1381 & 3 & 11 \\
\hline Performance & $\begin{array}{l}=\sum \mathrm{f}_{\mathrm{j}} / \mathrm{n} \text {, where the } \mathrm{f}_{\mathrm{j}} \text { is the reported scores (between } 0-100 \text { ) for each relevant } \\
\text { factor, averaged over all factors to } n \text { which were applicable. }\end{array}$ & 67.3467 & 8.1036 & 49.11 & 90.43 \\
\hline ProdDiff & $=1$ (Identical), =2 (Similar), =3 (Different) & 2.1746 & 0.7733 & 1 & 3 \\
\hline PTemployees & Number of part-time employees at start-up. & 2.9115 & 11.0609 & 0 & 140 \\
\hline Rival & The number of major rivals. & 26.0318 & 126.1867 & 0 & 1000 \\
\hline Sector & $=0$ services $($ SIC 61-99), 1 =manufacturing (SIC 01-60). & .6042 & .49031 & 0 & 1 \\
\hline Size & Number of full-time equivalent employees in 2001. & 13.6508 & 19.8488 & 1 & 130 \\
\hline Strategy & $\begin{array}{l}=\sum f_{j} \text { where } f_{j} \text { are counts of the forms of competitive strategy used by the } \\
\text { firm in their principal markets (e.g. marketing, new product development). }\end{array}$ & 4.5397 & 1.8035 & 1 & 8 \\
\hline StSales & $\begin{array}{l}\text { Sales at first interview (1985 for Leverhulme 1985-1988, } 1991 \text { for } \\
\text { Telephone 1991, } 1994 \text { for Leverhulme 1994-1997) at 2001 prices. }\end{array}$ & 364967 & 398350 & 19472 & 2543577 \\
\hline StYear & Year the business was established. & 1979 & 9.1931 & 1936 & 1991 \\
\hline Survival & $=1$ survivor, 0 otherwise. & 0.3281 & 0.4708 & 0 & 1 \\
\hline TechnicalChange & $\begin{array}{l}=1 \text { great technical change in their industry over the life of the business, }=0 \\
\text { otherwise. }\end{array}$ & 0.8254 & 0.3827 & 0 & 1 \\
\hline
\end{tabular}


Table 4. Tests for evidence of endogeneity and exogeneity

Tests for evidence of endogeneity

\begin{tabular}{|c|c|c|c|c|}
\hline Equation & \multicolumn{2}{|c|}{ (4) } & (5) & (6) \\
\hline Function & \multicolumn{2}{|c|}{ Performance $_{i}=f\left(\right.$ Size $_{i}$, Strategy $\left._{i}\right)$} & Size $_{i}=g\left(\right.$ Performance $\left._{i}\right)$ & Strateg $_{i}=$ h $\left(\right.$ Performance $\left._{i}\right)$ \\
\hline Test Variable & Size $_{i}$ & Strategy $_{i}$ & Performance $_{i}$ & Performance $_{i}$ \\
\hline F-value & 2.12 & 0.99 & 8.2 & 3.35 \\
\hline Prob $>$ F & 0.1511 & 0.3236 & 0.0058 & 0.0722 \\
\hline
\end{tabular}

Tests for evidence of exogeneity given that Size $_{i}$ Strategy $_{i}$ and Performance $e_{i}$ are assumed to be endogenous.

\begin{tabular}{|c|c|c|c|c|c|c|c|}
\hline Equation & \multicolumn{3}{|c|}{ (4) } & \multicolumn{2}{|l|}{ (5) } & \multicolumn{2}{|c|}{ (6) } \\
\hline Function & Perf & mance $_{i}=f\left(\right.$ Size $_{i}$, & trategy $\left._{i}\right)$ & Size $_{i}=g($ Perforn & ance $\left._{i}\right)$ & Strategy $_{i}=h(F$ & rformance ${ }_{i}$ ) \\
\hline Test Variable & Liabilities $_{i}$ & Mainmarket $_{i}$ & TechnicalChange $_{i}$ & TechicalChange $_{i}$ & OrgCap $_{i}$ & Rivals $_{i}$ & ProdDiff $_{i}$. \\
\hline$F$-value & 1.58 & 1.12 & 0.02 & 0.41 & 6.671 & 1.51 & 3.30 \\
\hline Prob $>F$ & 0.214 & 0.2954 & 0.8794 & 0.5228 & 0.0119 & 0.2241 & 0.0746 \\
\hline
\end{tabular}


Table 5. I3SLS estimations

\begin{tabular}{|c|c|c|c|}
\hline & I & II & III \\
\hline & I3SLS & $\begin{array}{c}\text { I3SLS } \\
\text { Corrected for } \\
\text { Sample Selection } \\
\text { Bias }\end{array}$ & $\begin{array}{c}\text { I3SLS } \\
\text { Corrected for } \\
\text { Sample Selection } \\
\text { Bias }\end{array}$ \\
\hline Equations & Coefficient $(t$ stat $)$ & Coefficient $(t$ stat $)$ & Elasticity at Mean \\
\hline $\begin{array}{l}\text { Performance }_{i}= \\
\beta_{0} \\
+\beta_{1} \text { Size }_{\mathbf{i}} \\
+\beta_{2} \text { Strategy }_{\mathbf{i}} \\
+\beta_{3} \text { TechnicalChange }_{\mathbf{i}} \\
+\beta_{4} \text { Liabilities }_{\mathbf{i}} \\
+\beta_{5} \text { MainMarket }_{\mathbf{i}} \\
+\beta_{6} \text { Age }_{\mathbf{i}} \\
+\beta_{7} \text { Age }_{i} \\
+\beta_{8} \text { IMR }\end{array}$ & $\begin{array}{r}\mathbf{5 4 . 9 9 6}(10.65) \\
-\mathbf{0 . 1 7 5 4}(-2.87) \\
\mathbf{2 . 1 5 9 4}(1.83) \\
\mathbf{1 0 . 0 9}(4.46) \\
\mathbf{- 0 . 9 1 7 3}(-1.402) \\
\mathbf{0 . 1 4 1 4}(0.2378) \\
-\mathbf{0 . 1 4 1 6 5}(-1.099) \\
\mathbf{0 . 0 0 1 7}(1.204)\end{array}$ & $\begin{array}{r}\mathbf{4 2 . 1 7 6}(5.485) \\
\mathbf{- 0 . 2 1 4 1}(-3.742) \\
\mathbf{1 . 9 5 8 1}(1.765) \\
\mathbf{1 0 . 1 1}(4.684) \\
\mathbf{- 0 . 9 9 6 3}(-1.585) \\
\mathbf{0 . 4 1 1 7}(0.709) \\
-\mathbf{0 . 1 3 9 6}(-1.148) \\
\mathbf{0 . 0 0 1 8}(1.291) \\
\mathbf{1 2 . 9 1 1}(2.328) \\
\end{array}$ & $\begin{array}{r}-0.0434 \\
0.1320 \\
0.1240 \\
-0.0270 \\
0.0139 \\
-0.0529 \\
0.0239 \\
0.2035 \\
\end{array}$ \\
\hline $\begin{array}{l}\operatorname{Size}_{i}= \\
\alpha_{0} \\
+\alpha_{1} \text { Performance }_{\mathrm{i}} \\
+\alpha_{2} \text { TechnicalChange }_{\mathrm{i}} \\
+\alpha_{3} \text { BaseSalesRatio }_{\mathrm{i}} \\
+\alpha_{4} \text { OrgCap }_{\mathrm{i}} \\
+\alpha_{5} \mathrm{IMR}\end{array}$ & \begin{tabular}{|r|}
$\mathbf{1 3 3 . 0 8}(2.71)$ \\
$-\mathbf{2 . 1 8 3 1}(-2.896)$ \\
$\mathbf{2 3 . 0 4 9}(2.738)$ \\
$\mathbf{- 1 . 1 4 E - 0 5}(-0.7666)$ \\
$\mathbf{1 . 3 6 1 8}(1.747)$
\end{tabular} & $\begin{array}{r}\mathbf{9 1 . 0 7 0}(2.019) \\
-\mathbf{1 . 9 7 2 4}(-2.865) \\
\mathbf{2 0 . 3 4 2}(2.616) \\
-\mathbf{1 . 2 2 E - 0 5}(-0.792) \\
\mathbf{1 . 3 6 2 8}(1.855) \\
\mathbf{2 8 . 3 9 5 8}(1.560)\end{array}$ & $\begin{array}{r}-9.7309 \\
1.2230 \\
-0.1014 \\
0.7226 \\
2.2084\end{array}$ \\
\hline$\left\{\begin{array}{l}\text { Strateg }_{i}= \\
\gamma_{0} \\
+\gamma_{1} \text { Performance }_{\mathbf{i}} \\
+\gamma_{2} \text { Rival }_{\mathbf{i}} \\
+\gamma_{3} \text { ProdDiff }_{\mathbf{i}} \\
+\gamma_{4} \text { IMR }\end{array}\right.$ & $\begin{array}{r}\mathbf{7 . 3 8 5 7}(2.122) \\
\mathbf{- 5 . 9 5 E - 0 2}(-1.139) \\
\mathbf{- 7 . 5 4 E - 0 3}(-4.361) \\
\mathbf{0 . 6 2 5 4}(2.463)\end{array}$ & $\begin{array}{r}\mathbf{7 . 0 9 8 8}(1.987) \\
\mathbf{- 0 . 0 8 0 9}(-1.454) \\
\mathbf{- 0 . 0 0 8 3}(-4.541) \\
\mathbf{0 . 7 1 3 4}(2.650) \\
\mathbf{1 . 4 6 1 4}(0.886)\end{array}$ & \begin{tabular}{r|}
-1.2002 \\
-0.0476 \\
0.3417 \\
0.3418
\end{tabular} \\
\hline Iterations & & & \\
\hline
\end{tabular}

Notes:

(a) Dependent Variable is Performance [ $\mathrm{N}=63$, mean=67.35, standard deviation=8.10].

(b) Selection Equation $(N=186)$ where $\hat{y}$ is survival.

$\begin{array}{rlll}\hat{y}= & -0.4174+0.019 \text { Sector }-0.0037 \text { FTemployees }-0.014 \text { PTemployees }-0.0017 \text { StYear }+0.478 \mathrm{E}(-06) \text { StSales } \\ (-0.443) & (0.095) & (-0.324) & (-1.179)\end{array}$

(c) $\mathrm{T}$ statistics are in parentheses. 
Table 6. I3SLS estimations Corrected for Sample Selection Bias Using Comparator Performance Dimensions

\begin{tabular}{|c|c|c|c|c|c|}
\hline $\begin{array}{l}\text { Dimensions of } \\
\text { Performance }\end{array}$ & ALL & Internal & Environment & Strategy & Finance \\
\hline Equations & $\begin{array}{c}\text { Coefficient } \\
(t \text { stat })\end{array}$ & $\begin{array}{c}\text { Coefficient } \\
(t \text { stat })\end{array}$ & $\begin{array}{c}\text { Coefficient } \\
(t \text { stat })\end{array}$ & $\begin{array}{c}\text { Coefficient } \\
(t \text { stat })\end{array}$ & $\begin{array}{c}\text { Coefficient } \\
(t \text { stat })\end{array}$ \\
\hline \multicolumn{6}{|l|}{ Performance $_{i}=$} \\
\hline$\beta_{0}$ & $\mathbf{4 2 . 1 7 6}(5.485)$ & $\mathbf{3 8 . 5 7 5 4}(3.113)$ & $\mathbf{5 1 . 0 2 6 1}(5.729)$ & $\mathbf{3 8 . 9 0 7 9}(3.5800)$ & $\mathbf{2 0 . 3 9 8 1}(1.0050)$ \\
\hline$+\beta_{1}$ Size $_{i}$ & $\mathbf{- 0 . 2 1 4 1}(-3.742)$ & $\mathbf{- 0 . 3 7 6 8}(-3.973)$ & $\mathbf{- 0 . 3 4 9 3 5}(-8.075)$ & $\mathbf{- 0 . 2 6 9 1}(-3.3590)$ & $\mathbf{- 0 . 2 7 1 1}(-1.6600)$ \\
\hline$+\beta_{2}$ Strategy $_{i}$ & $\mathbf{1 . 9 5 8 1}(1.765)$ & $\mathbf{1 4 . 0 7 5 6}(3.491)$ & $\mathbf{7 . 6 8 5 3}(2.956)$ & $\mathbf{9 . 7 2 7 5}(3.1360)$ & $\mathbf{1 6 . 5 7 3 3}(3.0730)$ \\
\hline$+\beta_{3}$ TechnicalChange $_{i}$ & $\mathbf{1 0 . 1 1}(4.684)$ & $\mathbf{0 . 4 8 5 7}(0.305)$ & $\mathbf{1 . 0 1 5 6}(0.982)$ & $\mathbf{1 . 7 8 0 7}(1.2140)$ & $\mathbf{5 . 6 8 0 6}(1.8400)$ \\
\hline$+\beta_{4}$ Liabilities $_{i}$ & $\mathbf{- 0 . 9 9 6 3}(-1.585)$ & $\mathbf{0 . 0 6 1 4}(0.154)$ & $\mathbf{- 0 . 3 7 4 5}(-0.732)$ & $\mathbf{- 0 . 6 8 4 2}(-0.8140)$ & $\mathbf{- 3 . 6 9 2 3}(-2.0190)$ \\
\hline$+\beta_{5}$ MainMarket $_{i}$ & $\mathbf{0 . 4 1 1 7}(0.709)$ & $\mathbf{- 0 . 3 0 6 1}(-0.298)$ & $\mathbf{0 . 1 3 9 1}(0.359)$ & $\mathbf{0 . 5 5 0 7}(0.6150)$ & $\mathbf{0 . 5 3 6 2}(0.3250)$ \\
\hline$+\beta_{6}$ Age $_{i}$ & $\mathbf{- 0 . 1 3 9 6}(-1.148)$ & $\mathbf{0 . 0 4 6 0}(0.46)$ & $\mathbf{- 0 . 0 9 7 5}(-0.929)$ & $\mathbf{- 0 . 0 6 6 9}(-0.4260)$ & $\mathbf{- 0 . 1 1 1 1}(-0.3280)$ \\
\hline$+\beta_{7} \mathbf{A g e}_{\mathbf{i}}^{2}$ & $\mathbf{0 . 0 0 1 8}(1.291)$ & $\mathbf{- 0 . 0 0 0 4}(-0.485)$ & $\mathbf{0 . 0 0 1 2}(0.923)$ & $\mathbf{0 . 0 0 0 9}(0.4830)$ & $\mathbf{0 . 0 0 2 5}(0.6570)$ \\
\hline$+\beta_{8}$ IMR & $\mathbf{1 2 . 9 1 1}(2.328)$ & $\mathbf{2 5 . 9 8 8 1}(2.474)$ & $\mathbf{7 . 1 9 6 8}(1.019)$ & $\mathbf{2 1 . 1 2 8 5}(2.5920)$ & $\mathbf{9 . 0 8 8 1}(0.6520)$ \\
\hline \multicolumn{6}{|l|}{ Size $_{i}=$} \\
\hline$\alpha_{0}$ & $91.070(2.019)$ & 133.2721(1.462)\| & $\mathbf{1 2 0 . 2 6 2 8}(2.881)$ & $\mathbf{6 7 . 9 2 4 7}(1.0420)$ & $20.3420(0.6710$ \\
\hline$+\alpha_{1}$ Perfo & $\mathbf{- 1 . 9 7 2 4}(-2.865)$ & $\mathbf{- 3 . 0 2 9 5}(-2.183)$ & $\mathbf{- 2 . 2 1 1 1}(-3.496)$ & $\mathbf{- 1 . 6 7 1 8}(-1.8000)$ & $\mathbf{- 0 . 6 4 7 5}(-1.7660)$ \\
\hline$+\alpha_{2} \mathbf{T}$ & $\mathbf{2 0 . 3 4 2}(2.616)$ & $41.2602(2.273)$ & $\mathbf{1 5 . 9 2 2 5}(2.272)$ & $\mathbf{1 9 . 5 5 1 8}(2.0510)$ & $\mathbf{1 3 . 6 9 5 3}(1.846$ \\
\hline$+\alpha_{3}$ BaseSalesRatio $_{i}$ & -1.22E-05 $(-0.792)$ & $\mathbf{- 0 . 7 6 E - 0 5}(-0.286)$ & $\mathbf{- 0 . 6 7 E - 0 5}(-0.606)$ & $\mathbf{- 0 . 8 0 E - 0 5}(-0.3260)$ & $-\mathbf{0 . 2 4 E - 0 4}(-1.2420$ \\
\hline$+\alpha_{4} \operatorname{OrgCap}_{\mathrm{i}}$ & $\mathbf{1 . 3 6 2 8}(1.855)$ & $\mathbf{0 . 3 5 9 2}(-0.374)$ & $\mathbf{0 . 4 6 5 4}(1.08)$ & $\mathbf{1 . 3 7 5 7}(1.6230)$ & $\mathbf{1 . 9 4 5 7}(2.1280)$ \\
\hline$+\alpha_{5}$ IMR & 28.3958 $(1.560)$ & $\mathbf{7 2 . 7 7 2 5}(2.554)$ & $\mathbf{1 6 . 0 5 2 9}(0.792)$ & $\mathbf{3 9 . 8 5 5 2}(1.9600)$ & $\mathbf{8 . 7 0 3 5}(0.4700)$ \\
\hline \multicolumn{6}{|l|}{ Strategy $y_{i}=$} \\
\hline$\gamma_{0}$ & $7.0988(1.987)$ & $\mathbf{3 . 1 3 1 5}(1.034)$ & $\mathbf{1 0 . 7 7 4 0}(2.351)$ & $\mathbf{3 . 3 5 6 2}(1.0590)$ & $\mathbf{4 . 4 0 8 4}(1.85)$ \\
\hline$+\gamma_{I}$ Performa & $\mathbf{- 0 . 0 8 0 9}(-1.454)$ & $\mathbf{- 0 . 0 1 6 0}(-0.369)$ & $\mathbf{- 0 . 1 3 6 5 2}(-1.942)$ & $\mathbf{- 0 . 0 1 3 2}(-0.2710)$ & $\mathbf{- 0 . 0 4 1 1}(-1.3580)$ \\
\hline$+\gamma_{2}$ Rival $_{i}$ & $\mathbf{- 0 . 0 0 8 3}(-4.541)$ & $\mathbf{- 0 . 0 0 4 0}(-2.452)$ & $\mathbf{- 0 . 0 1 0 2 9}(-4.256)$ & $\mathbf{- 0 . 0 0 5 1}(-3.0970)$ & $\mathbf{- 0 . 0 0 7 1}(-4.0850)$ \\
\hline$+\gamma_{3}$ ProdD & $\mathbf{0 . 7 1 3 4}(2.650)$ & $\mathbf{0 . 8 5 0 4}(3.124)$ & $\mathbf{0 . 7 1 6 6}(2.448)$ & $\mathbf{0 . 6 9 8 3}(2.6780)$ & $\mathbf{0 . 8 6 0 3}(2.9940)$ \\
\hline$+\gamma_{4}$ IMR & $\mathbf{1 . 4 6 1 4}(0.886)$ & $\mathbf{0 . 8 1 4 0}(0.507)$ & $\mathbf{1 . 0 1 9 7}(0.546)$ & $\mathbf{0 . 7 1 6 9}(0.4500)$ & $\mathbf{0 . 8 4 6 4}(0.5530)$ \\
\hline
\end{tabular}

Notes:

(a) Dependent Variable is Performance $[\mathrm{N}=63$, mean $=67.35$, standard deviation $=8.10]$.

(b) Selection Equation $(N=186)$ where $\hat{y}$ is survival.

$\hat{y}=-0.4174+0.019$ Sector -0.0037 FTemployees -0.014 PTemployees -0.0017 StYear $+0.478 \mathrm{E}(-06)$ StSales $\begin{array}{lllll}(-0.443) & (0.095) & (-0.324) & (-1.179) & (-0.146)\end{array}$

(c) $\mathrm{T}$ statistics are in parentheses. 
Figure 1. Response Format for Long Run Performance

4.1 We'd like to know what has kept you in business down the years. Some things are good for business and some things are bad. What effect have the following had?

[Show with a cross whether the effect was good or bad.]

Debt

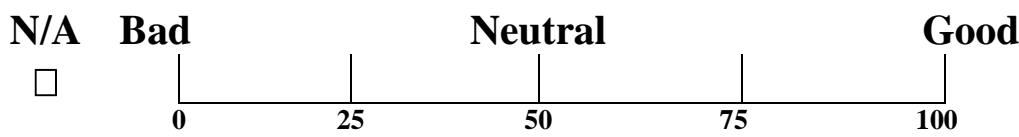

Operational Efficiency

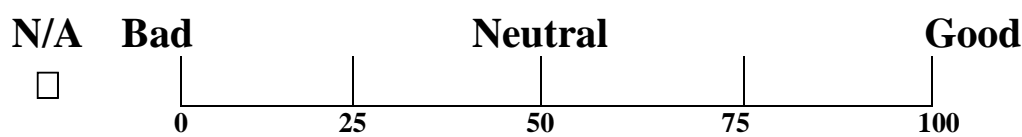

Cashflow

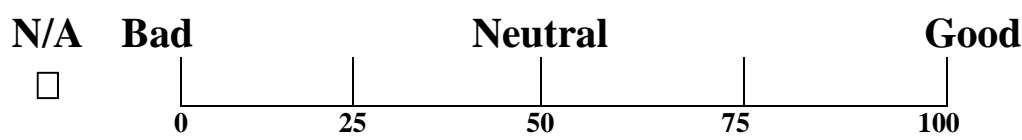


Figure 2: Size Performance Trade-off

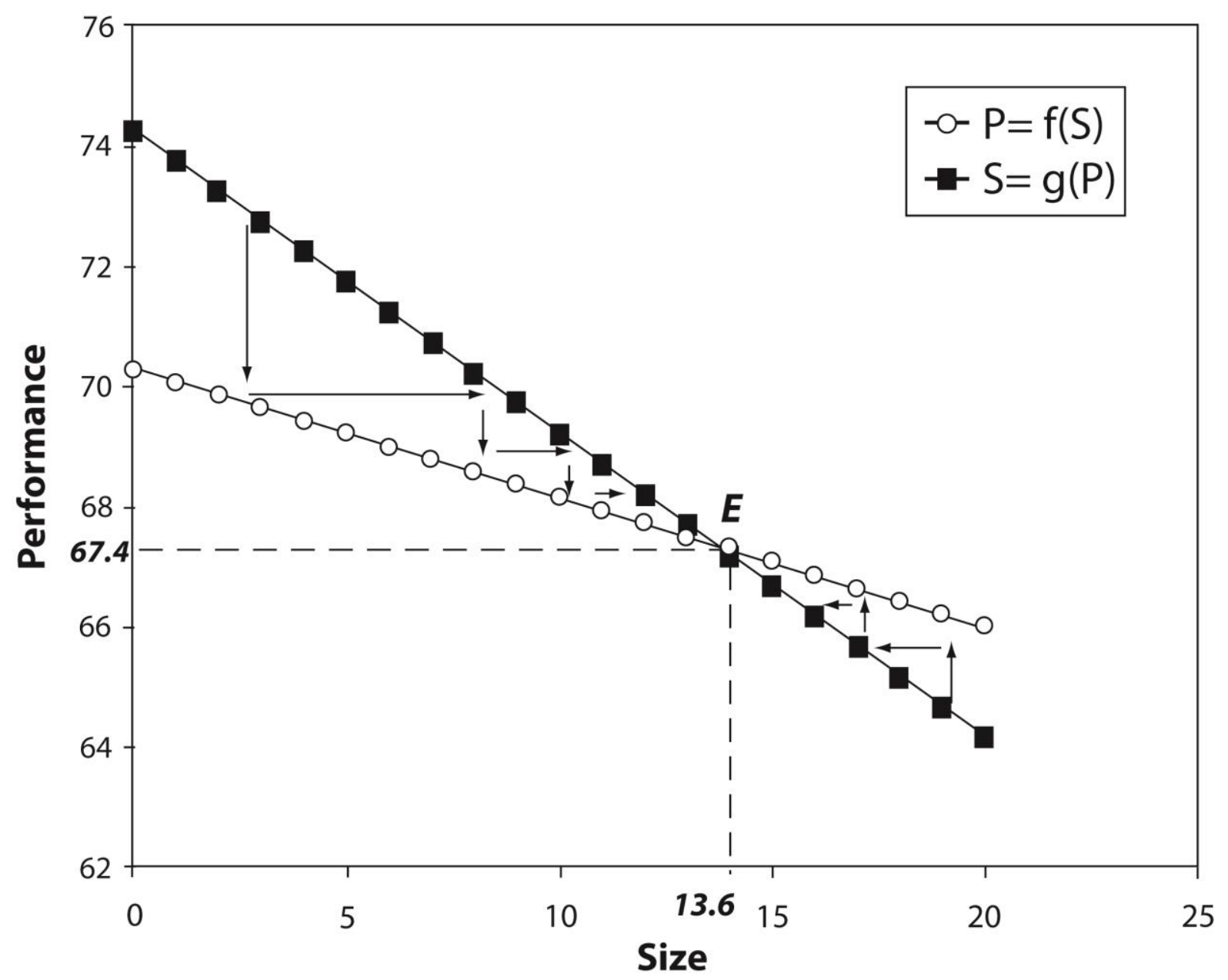


Figure 3: Impact of an increase in the diversity of competitive strategy

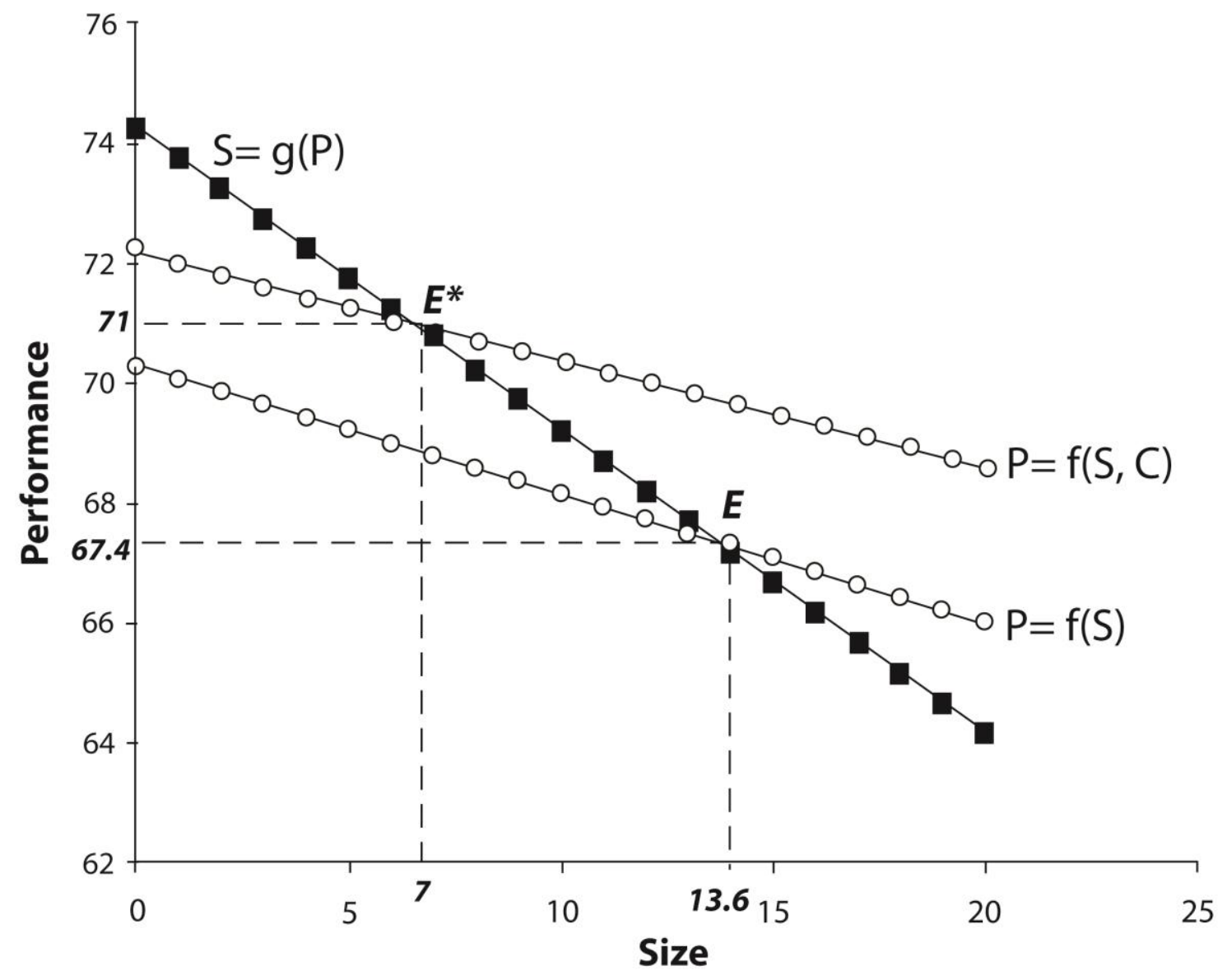




\section{Notes}

${ }^{1}$ Storey (1994) found that $4 \%$ of the fast growing firms in his sample create about $50 \%$ of the employment in this cohort over a decade.

${ }^{2}$ SMEs are defined in accordance to the European Commission's definition 2003/361/EC definition where medium-sized enterprises consists of enterprises which employ fewer than 250 persons and which have either an annual turnover not exceeding 50 million euro, or an annual balance sheet total not exceeding 43 million euro. Small enterprises are defined as enterprises which employ fewer than 50 persons and whose annual turnover or annual balance sheet total does not exceed 10 million euro. Micro enterprises are defined as enterprises which employ fewer than 10 persons and whose annual turnover or annual balance sheet total does not exceed 2 million euro.

${ }^{3}$ See Jacobsen (1986).

${ }^{4}$ See Reid and Andersen (1992).

${ }^{5}$ See Smith (1997).

${ }^{6}$ See the online appendix for a more detailed presentation of the exact survey question and all 28 items included in this multidimensional performance measure.

${ }^{7}$ Specifically, the Cronbach's (1951) alpha was 0.78, exceeding the level recommended by Nunnally (1978) of 0.7 and the data fitted yardstick measurement models (cf. Sandberg and Hofer, 1987; Chrisman, Bauerschmidt. and Hofer 1998) well $\left[\chi^{2}(16)=9.9762\right.$; prob. value $\left.=0.868\right]$.

${ }^{8}$ In practice the test is implemented as follows: Suppose a structural equation is

$\mathrm{y}_{1}=\boldsymbol{\delta} \mathrm{X}_{1}+\beta \mathrm{y}_{2}+\mathrm{u}$

where $y_{1}$ and $y_{2}$ are vectors of suspected endogenous variables, $X_{1}$ is a matrix of exogenous and predetermined variables, and $u$ a vector of error terms. Let $\hat{y}_{2}$ be the vector of fitted values of $y_{2}$ from a reduced form regression of $y_{2}$ against all the exogenous and predetermined variables in the system. The DWH test is simply an F test that the coefficient $\pi$ on $\hat{y}_{2}$ is equal to zero (i.e. test $\hat{\pi}=0$ ) in an estimation of the following regression $\mathrm{y}_{1}=\delta \mathrm{X}_{1}+\beta \mathrm{y}_{2}+\pi \hat{\mathrm{y}}_{2}+\mathrm{u}$.

${ }^{9} \mathrm{~F}_{(1,60)}$ statistic $=0.17, \mathrm{H}_{\mathrm{o}}$ could not be rejected.

${ }^{10} \mathrm{~F}_{(1,60)}$ statistic $=0.57, \mathrm{H}_{\mathrm{o}}$ could not be rejected.

${ }_{11}^{11}$ Maximum likelihood methods are invariant to reparameterisation whereas instrumental variables are not.

${ }^{12}$ The I3SLS estimation and the associated diagnostic tests were conducted on Shazam whereas the I3SLS estimation with the correction for sample selection was undertaken in LIMDEP.

${ }^{13}$ When higher that 2 iterations are used the significance of the performance and size variables increase rapidly due to rounding errors.

${ }^{14}$ Single $\mathrm{R}^{2}$ measures are not appropriate in an equation system. The $\mathrm{R}^{2}$ from a particular equation computed could be negative since with system estimation in general it is not the case within each equation the sum of the residuals is zero. The numerator could be larger than the denominator that is the unexplained variation can be larger than the total variation implying a negative $\mathrm{R}^{2}$. This is because single equation systems minimises e'e and therefore maximises the $\mathrm{R}^{2}$ in general. System estimation methods do not minimise e'e. The maximum likelihood estimator minimises the determinant of the residual cross products matrix; that is ML minimises det E'E. Hence ML does not maximise the individual equation $\mathrm{R}^{2}$ values. Since single equation $\mathrm{R}^{2}$ measures are flawed in the equation system context, a different goodness of fit measure should be employed vis. $\tilde{R}^{2}=1-\frac{\left|E^{\prime} E\right|}{\left|y^{\prime} y\right|}$

The system $\tilde{R}^{2}$ reported is defined as

$$
\tilde{R}=1-|\hat{\Sigma}| /(Y-\bar{Y})^{\prime}(Y-\bar{Y}) \mid
$$

where $\mathrm{Y}$ is an $n x k$ matrix and $\bar{Y}$ contains the sample means.

15 The Chi-square statistic is

$\chi^{2}=-N\left(\log \left(1-\widetilde{R}^{2}\right)\right)$

16 The Lagrange Multiplier statistic is computed as $L M^{*}=N R_{u}^{2}$ where $R_{u}^{2}$ is the uncentered $R^{2}$ or $R_{u}^{2}=y^{\prime} X\left(X^{\prime} X\right)^{-1} X^{\prime} y / y^{\prime} y$, see Cameron and Trivedi (2005). Under the null hypothesis of a diagonal 
covariance structure the statistic has an asymptotic $\chi_{(M(M-1) / 2)}^{2}$ distribution where $\mathrm{M}$ is the number of equations in the system.

${ }^{17}$ This stability condition can be expressed: $(\mathrm{dP} / \mathrm{dS})_{7 \mathrm{a}}=-0.2141>-0.5070=(\mathrm{dP} / \mathrm{dS})_{8}$ 